\title{
Apostolische Auslandsreisen von Papst Franziskus, darunter Missionsreisen, in den wichtigsten nationalen Internetportalen (Jahr 2016)
}

\author{
Apostolic journeys of Pope Francis, including missionary ones, \\ in the most important national websites (2016)
}

\begin{abstract}
ZUSAMMENFASSUNG:
Die Kirche bediente sich in ihrer Tätigkeit und bedient sich weiterhin der Medien. Am Anfang der Zeitschriften, des Radios, des Fernsehens, und schließlich auch des Internets und neuer Medien. Dieses letzte Medium verdrängt recht effektiv die früher genutzten Medien und wird ein Ort für Kommunizieren von Gedanken. In den vorgenommenen Forschungen wurden die wichtigsten meinungsbildenden Portale in Polen (www.onet.pl, www.wp.pl, www.interia. pl, www.gazeta.pl, www.o2.pl i www.fakt.pl) auf Veröffentlichung von Texten betreffend sechs apostolische Auslandsreisen, darunter

Missionsreisen, von Papst Franziskus im Jahre 2016 analysiert. Es wurden die Anzahl, die Qualität, die Art und die Zeit der Veröffentlichungen untersucht sowie pastorale Schlussfolgerungen bezüglich der Anwesenheit der Mission, der päpstlichen Pilgerfahrten sowie der ekklesischen Tätigkeit in Internet- und Laienportalen gezogen. Auf dieser Grundlage wurden folgende Forschungshypothesen beantwortet.

Es scheint, die erste: „Die Medien in

Polen informieren sachgemäß über die Auslandspilgerreisen von Papst Franziskus (quantitativ und qualitativ)“ sei unbestätigt. Die zweite: „Die Vorbereitung der Geistlichen zur Benutzung neuer Medien
\end{abstract}

und zur Benachrichtigung über die mit der Kirche verbundenen Fragen ist sachgemäß" sei unbestätigt; und die dritte: „Die Anzahl der Informationen und die Benachrichtigungsart über die Auslandspilgerreisen ist ungenügend" sei bestätigt.

\section{SCHLÜSSELWÖRTER:}

apostolische Reisen, Papst Franziskus, neue Medien, Internet, meinungsbildende Portale, Missionen, Kirche

\section{SUMMARY}

In its activity, the Catholic Church has used and uses the media. At the beginning, magazines, radio, television, and finally the Internet as well as so-called new media were taken into consideration. This latter one quite effectively displaces the previously used ones and becomes a place of communication. In the research undertaken, the most important Polish opinion leading websites were analyzed (www.onet.pl, www.wp.pl, www.interia.pl, www.gazeta.pl, www.o2.pl and www.fakt.pl) in terms of publishing texts concerning six foreign apostolic journeys of Pope Francis, including missionary ones in 2016. The number, quality, type and time of publication were examined, as well as 
pastoral conclusions regarding the presence of papal missions and ecclesiastical activities in secular websites. On this basis, answer the following hypotheses, the first one: "Media in Poland informs about pilgrimages Pope Francis (quantitative and qualitative)" - is unconfirmed. The second one: "Spiritual preparation for using new media and inform about issues related to the Church is appropriate" - is unconfirmed; third: "The number of information and the way of informing about pilgrimages is insufficient" - confirmed.

\section{KEYWORDS:}

apostolic journeys, pope Francis, new media, Internet, opinion leaders websites, mission, Catholic Church

\section{ZAGRANICZNE PODRÓŻE APOSTOLSKIE PAPIEŻA FRANCISZKA, W TYM MISYJNE, W NAJWAŻNIEJSZYCH KRAJOWYCH PORTALACH INTERNETOWYCH (ROK 2016)}

\section{STRESZCZENIE}

Kościół w swojej działalności posługiwał się i posługuje mediami. Na początku czasopismami, radiem, telewizją, aż w końcu Internetem i nowymi mediami. To ostatnie medium dość skutecznie wypiera wcześniej używane i staje się miejscem komunikowania myśli. W podjętych badaniach poddano analizie najważniejsze portale opiniotwórcze w Polsce (www.onet.pl, www.wp.pl, www. interia.pl, www.gazeta.pl, www.o2.pl i www.fakt.pl) pod względem publikowania tekstów dotyczących sześciu zagranicznych podróży apostolskich papieża Franciszka, w tym misyjnych, w roku 2016. Zbadano liczbę, jakość, rodzaj i czas publikacji, a także wysnuto wnioski pastoralne dotyczące obecności misji, pielgrzymek papieskich oraz działalności eklezjalnej w laickich portalach internetowych. Na tej podstawie odpowiedziano na następujące hipotezy badawcze, wydaje się, że pierwsza: „Media w Polsce właściwie informują o pielgrzymkach zagranicznych papieża Franciszka (ilościowo i jakościowo)” - jest niepotwierdzona. Druga: „Przygotowanie duchownych do posługiwania się nowymi mediami i informowania o zagadnieniach związanych z Kościołem jest odpowiednia” - jest niepotwierdzona; a trzecia: „Liczba informacji i sposób informowania o zagranicznych pielgrzymkach jest niewystarczająca" - potwierdzona.

\section{SŁOWA KLUCZOWE:}

podróże apostolskie, papież Franciszek, nowe media, Internet, portale opiniotwórcze, misje, Kościół

Qit Anfang der Existenz der sozialen Kommunikationsmittel weckte das Papst- amt das Interesse in Polen. Die Menschen interessierten sich für Neuheiten aus der Lehre der Päpste oder für Details aus dem Alltag des Apostolischen Stuhls. Zweifelsohne fiel die Gipfelzeit dieses Interesses für den Pontifikat von Johannes Paul II an. 
Marcin Wrzos, Apostolische Auslandsreisen von Papst Franziskus, darunter Missionsreisen...

Jorge Mario Bergoglio SJ (geb. am 17. Dezember 1936 in Buenos Aires) - argentinischer römisch-katholischer Geistliche wurde am 13. März 2013 zum 266. Papst. Seit Anfang an weckte sein Pontifikat Interesse der weltweiten und der polnischen sozialen Kommunikationsmittel. Insbesondere gilt es für die Frage der Flüchtlinge oder der Lehre betreffend die Ehe und die Lebensübertragung.

Das Internet, darunter seine Vermittlung nutzende neue Medien ${ }^{1}$, verdrängt langsam die Papierversionen der Zeitschriften, das Radio und das Fernsehen, daher wurde es ein Ort, wo Veröffentlichungen über den Papst platziert werden. Gerade in diesem Gebiet erfolgt derzeit, wie es scheint, der größte Fluss von Informationen, Ideen und Gedanken. Die beliebtesten publizistischen und Informationsdienste in Polen sind: www.onet.pl, www.wp.pl, www.interia.pl, www. gazeta.pl, www.o2.pl i www.fakt.pl. Es ist erwähnenswert, dass das Portal www. onet.pl die größte Lesergruppe hat, das ein Niveau von 15,8 Mio. Nutzer monatlich erreicht, was rund 60\% der Internetnutzer in Polen entspricht, und das Portal www.fakt.pl die kleinste (entsprechend 4,4 Mio., d. h. 20\% der Nutzer)22. Diese Portale haben somit eine riesige meinungsbildende Rolle, die die Haltung seiner Nutzer bildet, umso mehr, dass der Anteil der christlichen und katholischen Portale am Merkt gering ist ${ }^{3}$.

${ }^{1}$ Für die Forschungen nehmen wir eine der verfügbaren Definitionen neuer Medien annehmen, wo neue Medien sind „Techniken, Technologien sowie Institutionen, die zur Kommunikation dienen, und die digitale Verfahren zur Erfassung, Aufzeichnung und Speicherung von Daten, zur Erstellung und Übertragung von Übermittlungen nutzen sind. Neue Medien zeichnen sich durch Hypertextstruktur der Übermittlung und des Empfangs, Programmierungsmöglichkeit (Asynchronie des Sendens und des Empfangs), Interaktivität, Kumulativität, globale Reichweite und gleichzeitig Individualisierung des Zugangs aus" - E. Chudziński (Red.), Słownik wiedzy o mediach, Warszawa - Bielsko-Biała 2007, S. 45.

${ }^{2}$ Siehe: Laut der Forschungen gehören zu den meinungsbildenden Portalen, die das Lesen auf dem Niveau von ca. 6 Mio. Nutzer in Polen erreichen: www.onet.pl (18,2 Mio. Nutzer, $60 \%$ Bereich im Internet), www.wp.pl (15,8 Mio., 47,7\%), www.interia.pl (13,9 Mio., 34,4\%), www.gazeta.pl (10,5 Mio., 26,8\%), www.o2.pl (6,91 Mio., 24,7\%) und www.fakt.pl (6,79 Mio., 24,25\%). Quelle: Megapanel PBI/Gemius, Januar 2018, Anzahl der Versuchspersonen: N=145 982, mit der Forschung umfasste Gruppe: 7-75 Jahre.

${ }^{3}$ Siehe: Laut dieser Forschungen waren die am häufigsten besuchten christlichen Webseiten: www.deon.pl (1,1 Mio. Nutzer, 3,95\%), www.opoka.org.pl (0,65 Mio., 2,33\%), www. wiara.pl (0,64 Mio., 2,31\%), www.niedziela.pl (0,51 Mio., 1,80\%), www.gloria.tv (0,50 Mio., 1,76\%). Quelle: Megapanel PBI/Gemius, Januar 2018, Anzahl der Versuchspersonen: N=145 982, mit der Forschung umfasste Gruppe: 7-75 Jahre. 
Die Kirche bemerkt die Notwendigkeit der Präsenz auf diesem Gebiet und ihre Lehre ist insbesondere in den Botschaften für den Tag der sozialen Kommunikationsmittel mit dem Erscheinen neuer Kanäle für Gedankenübermittlung verbunden. Neue Informationstechniken sind vielschichtig. Sie bilden nicht nur neue Werkzeuge für die Kirche, die zur Erfüllung ihrer Evangelisierungsmission dienen. Es ist auch der Raum, in dem die Kirche anwesend sein soll und den sie mit den Evangeliumswerten erfüllen soll. Theologen der sozialen Kommunikationsmittel weisen darauf hin, dass obwohl bis vor Kurzem „die Kirche Missionen führte und das Korn des Evangeliums vom Kontinent zum Kontinent übertrug, betritt sie um die Wende des 20. und 21. Jahrhunderts nach Geburt Christi einen ganz „neuen Boden“". Der erste Papst, der die besondere Bedeutung des Internets bemerkte, war Johannes Paul II. In der Botschaft zum Welttag der Massenmedien sprach er über eine „Ära der Computer" und die Verwendung von „computerisierten Beteiligungssystemen“, d. h. Internet, für die Umsetzung der Kirchenmission ${ }^{5}$. Papst Benedikt XVI. nennt das Internet ein „digitales Kontinent, das zu evangelisieren ist, das jedoch auch evangelisiert ${ }^{6 \text { " }}$, und Papst Franziskus stellt die Internetmedien als praktische Werkzeuge dar, die an der Kommunikation der Barmherzigkeit teilnehmen können ${ }^{7}$ und weist auch auf das Problem der Fake News hin ${ }^{8}$. Sofern die christlichen Internetportale umfangreich über die ekklesische Tätigkeit informieren und sie analysieren, wurden jedoch noch keine breiteren Forschungen ihrer Anwesenheit im Laienbereich des Internets vorgenommen.

Diese Forschung betrifft einen kleinen Abschnitt dieser Präsenz in den am meisten besuchten meinungsbildenden Portalen im Inland, was Gegenstand einer ausgefeilten Schlussfolgerung sein sollte. Es betrifft Papst Franziskus und seine

${ }^{4}$ J. Kloch, Kościół w Polsce wobec Web 2.0, Kielce 2013, S. 21.

${ }^{5}$ Siehe Johannes Paul II., Orędzie na 24. Światowy Dzień Środków Społecznego Przekazu, Misja Kościoła w erze komputerów. 24. Januar 1990.

${ }^{6}$ Siehe Benedikt XVI., Orędzie na 43. Światowy Dzień Środków Społecznego Przekazu. Nowe technologie, nowe relacje. Trzeba rozpowszechniać kulturę szacunku, dialogu i przyjaźni, 24. Januar 2009.

${ }^{7}$ Siehe Franziskus I., Orędzie na 50. Światowy Dzień Środków Społecznego Przekazu Komunikacja i Miłosierdzie - owocne spotkanie, 24. Januar 2016.

${ }^{8}$ Siehe Franziskus I., Orędzie na 52. Światowy Dzień Środków Społecznego Przekazu «Prawda was wyzwoli» (J 8, 32). Fake news a dziennikarstwo pokoju“ 24. Januar 2018. 
apostolischen Reisen im Jahre 2016. Die vorigen Jahre des Pontifikats wurden in den früheren Forschungen analysiert ${ }^{9}$. Der Forschungsprozess besteht aus zwei Stufen: Die erste ist die Bearbeitung der im Internet veröffentlichten Artikeln mit der Methode einer quantitativ-qualitativen Analyse des Inhalts. Dann nehmen wir eine theologisch-missionswissenschaftliche Analyse der erhaltenen Daten vor und ziehen pastorale Schlussfolgerungen. Die Forschungsarbeiten teilen wir somit auf Folgendes:

1. Inhaltsanalyse der Artikeln über die Missionsreisen von Papst Franziskus (2016) in den wichtigsten Portalen mit der quantitativ-qualitativen Methode. Die gesammelten Artikeln betreffen die folgenden Pilgerreisen:
a. 12.-17. Februar 2016 - Kuba, Mexiko;
b. 16. April 2016 - Griechenland;
c. 24.-.26 Juni 2016 - Armenien;
d. 27.-31. Juli 2016 - Polen;
e. 30. September - 2. Oktober 2016 - Georgien, Aserbaidschan;
f. 31. Oktober - 1. November 2016 - Schweden;

2. theologische Analyse der veröffentlichten Inhalte;

3. pastorale Schlussfolgerungen und Antwort auf die Forschungshypothesen: a.) Die Medien in Polen informieren sachgemäß über die Auslandspilgerreisen von Papst Franziskus (quantitativ und qualitativ); b.) Die Vorbereitung der Geistlichen zur Benutzung neuer Medien und zur Benachrichtigung über die mit der Kirche verbundenen Fragen ist sachgemäß; c.) Die Anzahl der Informationen und die Benachrichtigungsart über die Auslandspilgerreisen ist ungenügend.

${ }^{9}$ Siehe M. Wrzos, Zagraniczne podróże apostolskie, $w$ tym misyjne, papieża Franciszka w najważniejszych krajowych portalach internetowych, cz. I (lata 2013-2014), in: „Kultura-Media-Teologia", 1 (28) 2017, S. 111-141; Derselbe, Zagraniczne podróże apostolskie, w tym misyjne, papieża Franciszka w najważniejszych krajowych portalach internetowych, cz. II (rok 2015); in: „Kultura-Media-Teologia”, 4 (31) 2017, S. 140-179. 


\section{INHALTSANALYSE DER IN DEN WICHTIGSTEN PORTALEN VERÖFFENTLICHTEN ARTIKELN ÜBER DIE MISSIONSREISEN VON PAPST FRANZISKUS (2016) MIT DER QUANTITATIV-QUALITATIVEN METHODE}

\begin{tabular}{|c|c|}
\hline \multicolumn{2}{|c|}{ Methodologie der ersten Stufe der Forschungen } \\
\hline - Analysierte Zeit: & $\begin{array}{l}\text { a. 12. November } 2015 \text { - 17. Mai 2016; } \\
\text { b. 16. Januar } 2015 \text { - 16. Juli 2016; } \\
\text { c. 24. März } 2016 \text { - 26. September 2016; } \\
\text { d. 27. April } 2016 \text { - 31. Oktober 2016; } \\
\text { e. 30. Juni } 2016 \text { r. - 2 Januar 2017; } \\
\text { f. 31. Juli 2016. - 1. Februar 2017. } \\
\text { Drei Monate vor und drei Monate nach den päpstlichen Pilgerreisen; }\end{array}$ \\
\hline - Analysierte Dienste: & $\begin{array}{l}\text { www.onet.pl; www.wp.pl; www.interia.pl; www.gazeta.pl; www.o2.pl } \\
\text { und www.fakt.pl (meinungsbildende Portale mit dem Niveau von mind. } \\
\text { rund } 6 \text { Mio. Nutzern in Polen) }\end{array}$ \\
\hline - Inhaltsquellen: & Newspoint $t^{10}$ \\
\hline - Tiefe der Analyse: & $\begin{array}{l}\text { verbunden (automatisch und manuell) - in den erhaltenen Ergebnissen } \\
\text { der automatischen Suche nach den programmierten Algorithmen erfolgt } \\
\text { Selektion der Wahlrichtigkeit durch den Forscher. }\end{array}$ \\
\hline - Sprache der Quellen: & Polnisch \\
\hline - Sprache der Suche: & Polnisch \\
\hline $\begin{array}{l}\text { - Filtern von Spam/ } \\
\text { Boot-Dateien: }\end{array}$ & $\begin{array}{l}\text { verbunden (automatisch und manuell) - in den erhaltenen Ergebnissen } \\
\text { der automatischen Suche nach den programmierten Algorithmen erfolgt } \\
\text { Selektion der Wahlrichtigkeit durch den Forscher. }\end{array}$ \\
\hline - Schlüsselfragen/-wörter: & $\begin{array}{l}\text { a. Satz } 1 \text { [„Papst“ oder „Papst Franziskus” oder „päpstliche Pilgerreise” } \\
\text { oder „Besuch des Papstes“ oder „päpstlicher Besuch” oder „,apostoli- } \\
\text { scher Besuch”] und Satz } 2 \text { [„Havanna” oder „Mexico City” oder „Guada- } \\
\text { lupe” oder „Ecatepec” oder „Tuxtla Gutiérrez” oder „Tuxtla Gutierrez” } \\
\text { oder „San Cristóbal de las Casas” oder „San Cristobal de las Casas” } \\
\text { oder „San Cristóbal” oder „San Cristobal” oder „Ciudad Juárez” oder } \\
\text { „Ciudad Juarez” oder „Kuba“ oder „Mexiko“]. }\end{array}$ \\
\hline
\end{tabular}

${ }^{10}$ Newspoint ist ein das Internet überwachender Dienst, am meisten kommerziell, für Werbeauftraggeber sowie Träger, die ein Gewerbe im Internet betreiben. Es ist ein EDV-System zur Überwachung des Internets, der sozialen und traditionellen Medien. Es führte Analysen mit quantitativ-qualitativen Methoden, u. a. Inhaltsanalyse, CAWI, FGI, IDI durch. Es überwacht Internetdienste, Internetportale, Blogs, Foren, soziale Dienste (z. B. Faceboook), Mikroblogs (z. B. Twitter) und andere Dienste. Es wird zu Internetforschungen und zu Forschungen über Internetnutzer verwendet. Newspoint gehört zur Internationalen Vereinigung für Messung und Auswertung der Kommunikation (Association for Measurement and Evaluation of Communication, AMEC), die die Qualität der durchgeführten Analysen zertifiziert. 


\begin{tabular}{|c|c|}
\hline & 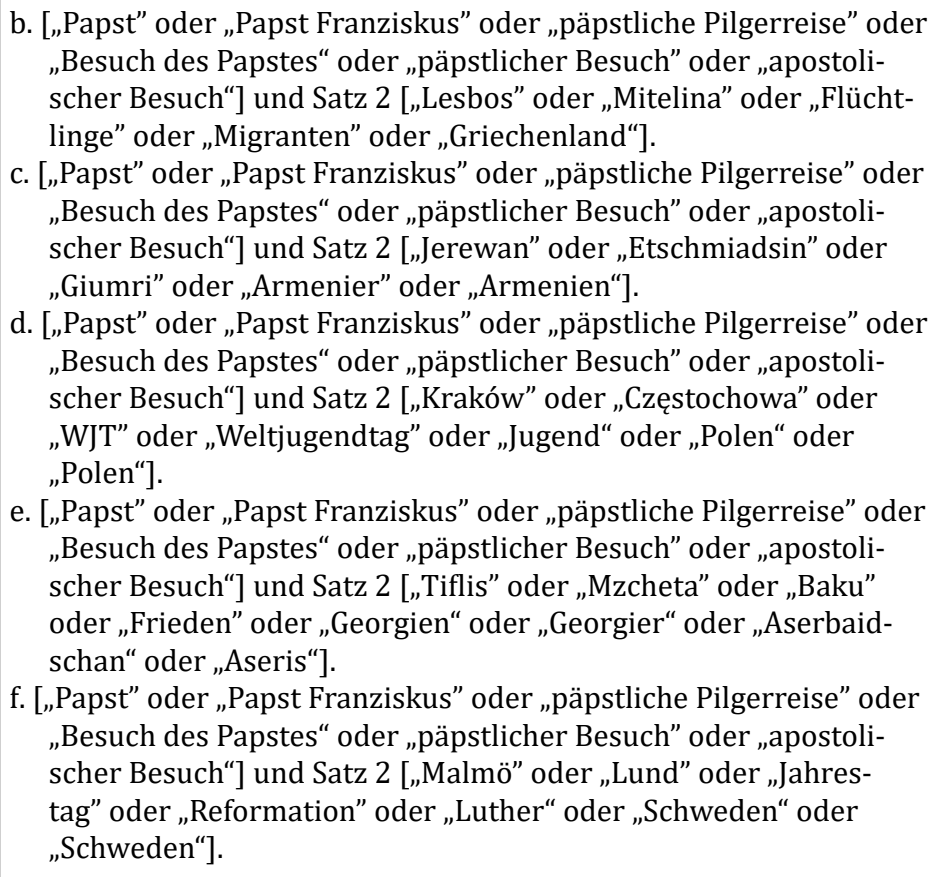 \\
\hline - Analyseeinheit: & $\begin{array}{l}\text { beliebiges Wort aus Satz } 1 \text { zzg. beliebiges Wort ais Satz 2, in beliebiger } \\
\text { Sprachversion; }\end{array}$ \\
\hline $\begin{array}{l}\text { - Anzahl der analysierten } \\
\text { Artikeln: }\end{array}$ & $\begin{array}{l}\text { a. } 83 ; \\
\text { b. } 32 ; \\
\text { c. } 20 ; \\
\text { d. } 1420 ; \\
\text { e. } 15 ; \\
\text { f. } 10 ; \Sigma=1580 \text {. }\end{array}$ \\
\hline
\end{tabular}

\subsection{2.-17. Februar 2016 - Kuba, Mexiko}

Die apostolische Reise von Papst Franziskus nach Kuba und Mexiko fand vom 12. bis zum 17. Februar 2016 statt. Der bereits zweite Besuch von Franziskus in Kuba war mit dem ersten in der Geschichte Gespräch des Oberhaupts der katholischen Kirche mit dem Oberhaupt russisch-orthodoxen Kirche, dem Patriarchen von Moskau und der ganzen Rus Kyrill I. (12. Februar 2016) verbunden. Der Besuch in Mexiko erfolgte unter dem Motto „Missionar der Barmherzigkeit und des Friedens“ (12.-17. Februar 2016). In Kuba besuchte der Papst eine Stadt: Havanna und in Mexiko: Mexico City, Guadalupe, Ecatepec, Tuxtla Gutiérrez, San Cristóbal de las Casas, Morelia und Ciudad Juárez. 
In den analysierten Portalen wurden 83 Texte zu diesem Thema veröffentlicht. Der erste war die Nachricht vom 12. Dezember 2015 im Portal www.gazeta.pl. Es war eine Ankündigung des geplanten Besuchs von Papst Franziskus in Mexiko. Der Autor wies auf den geplanten Aufenthalt des Papstes im Heiligtum Unsere Liebe Frau von Guadalupe ${ }^{11}$ hin. Die letzte Veröffentlichung erschien am 21. Februar 2016 im Portal www.wp.pl und es war eine Zusammenfassung der Pilgerreise. Es wurde aufs Gespräch mit dem Patriarchen von Moskau und der ganzen Rus Kyrill I. in Havanna hingewiesen. Der Papst appellierte um Aufhebung der Todesstrafe und auch des Missverhältnisses des Lebensstils zwischen den Reichen und den Armen ${ }^{12}$. Die mit der Pilgerreise verbundenen Berichte wurden während ihrer Dauer veröffentlicht. Es waren am häufigsten Pressemitteilungen

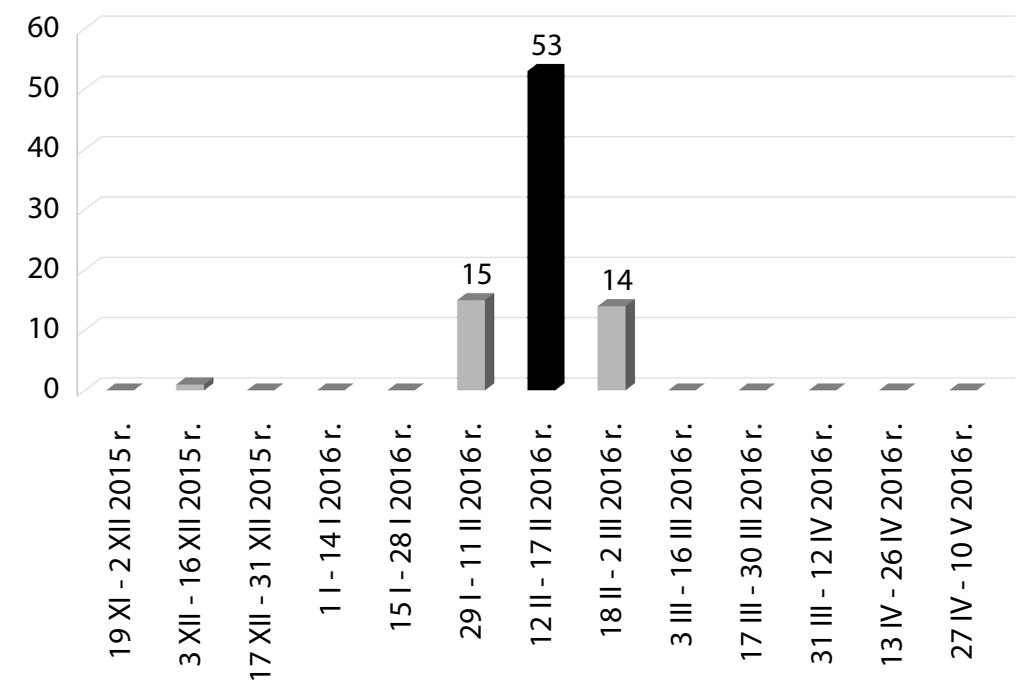

Diagramm Nr. 1. Anzahl der Publikationen zum Thema des Besuchs von Papst Franziskus in Kuba und in Mexiko in den polnischen Portalen nach dem Veröffentlichungstag, $\mathrm{N}=83$

Quelle: Newspoint

${ }^{11}$ Siehe [ohne Autor], Papież ogłosił, że w lutym 2016 roku odwiedzi Meksyk, 12.12.2015, in: http://wiadomosci.gazeta.pl/wiadomosci/1,114877,19336797,papiez-oglosil-ze-w-lutym-2016-roku-odwiedzi-meksyk.html, [Zugriff 15.03.2018].

${ }^{12}$ Siehe [ohne Autor], Papież wspomina spotkanie z Cyrylem i apeluje o zniesienie kary śmierci, 12.02.2016, in: http://wiadomosci.wp.pl/kat,1356,wid,18174771,martykul.html, [Zugriff 15.03.2018]. 
(53). Es gab 16 veröffentlichte Nachrichten in der Zeit vor der päpstlichen apostolischen Reise und 14 danach. Die letzte davon wurde vier Tage nach ihrer Beendigung veröffentlicht.

Die meisten Nachrichten zum Thema der päpstlichen Pilgerreise nach Kuba und Mexiko veröffentlichte das Portal www.gazeta.pl (44), was ihm rund 53\% des Anteils am Markt der Internetnachrichten zu diesem Thema ausmacht. Die weiteren Portale unter Berücksichtigung der Publikationsanzahl waren entsprechend: www.wp.pl (16), www.interia.pl (10) und www.onet.pl (8). Wenig Informationen zum analysierten Thema veröffentlichten www.fakt.pl (4) und www.o2.pl (1).

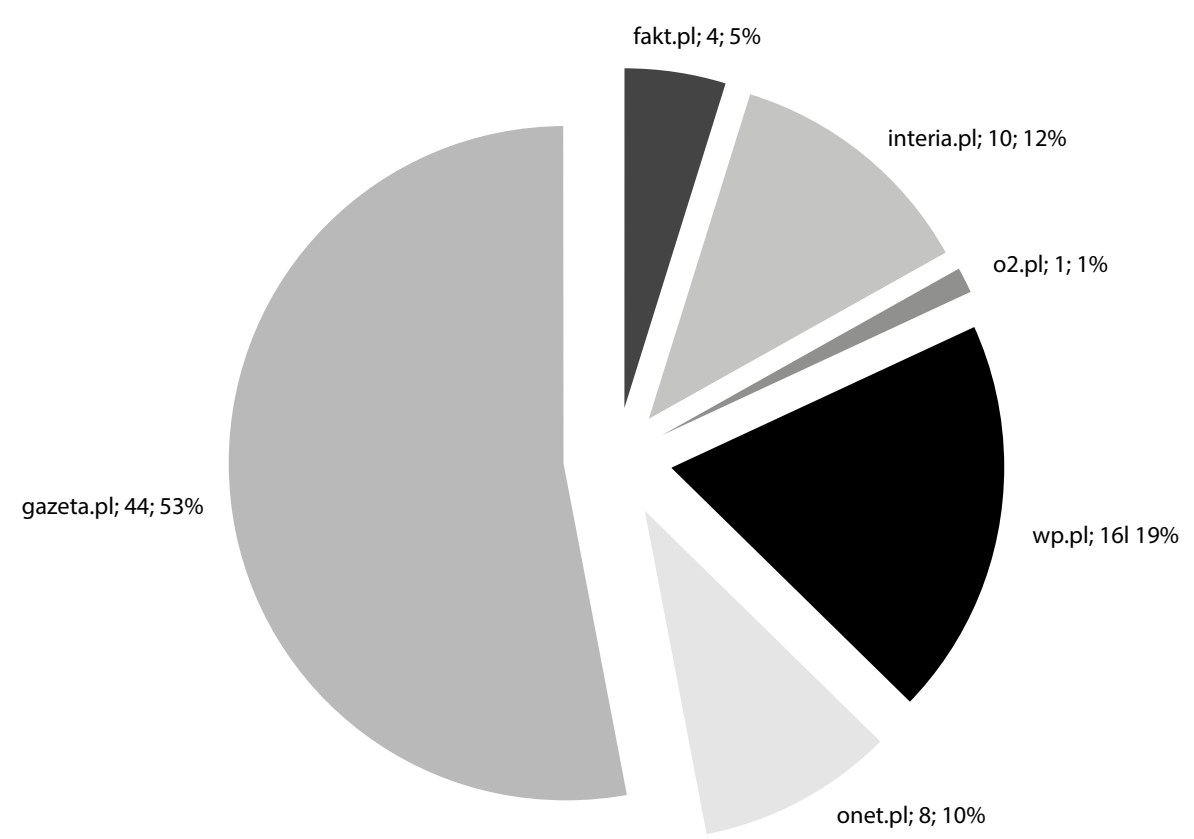

Diagramm Nr. 2. Anzahl der Publikationen zum Thema des Besuchs von Papst Franziskus in Kuba und in Mexiko in den polnischen Portalen nach dem Veröffentlichungsort, $\mathrm{N}=83$

Quelle: Newspoint

Weitere Stufe der auszuführenden Forschungen war Ermittlung der Kommunikationsweise über diese apostolische Pilgerreise von Papst Franziskus. Aus den durchgeführten Forschungen geht es hervor, dass 8/9 der veröffentlichten Nachrichten positiv (34) bzw. neutral waren (47). Es gab 2 negative Kommentare. 


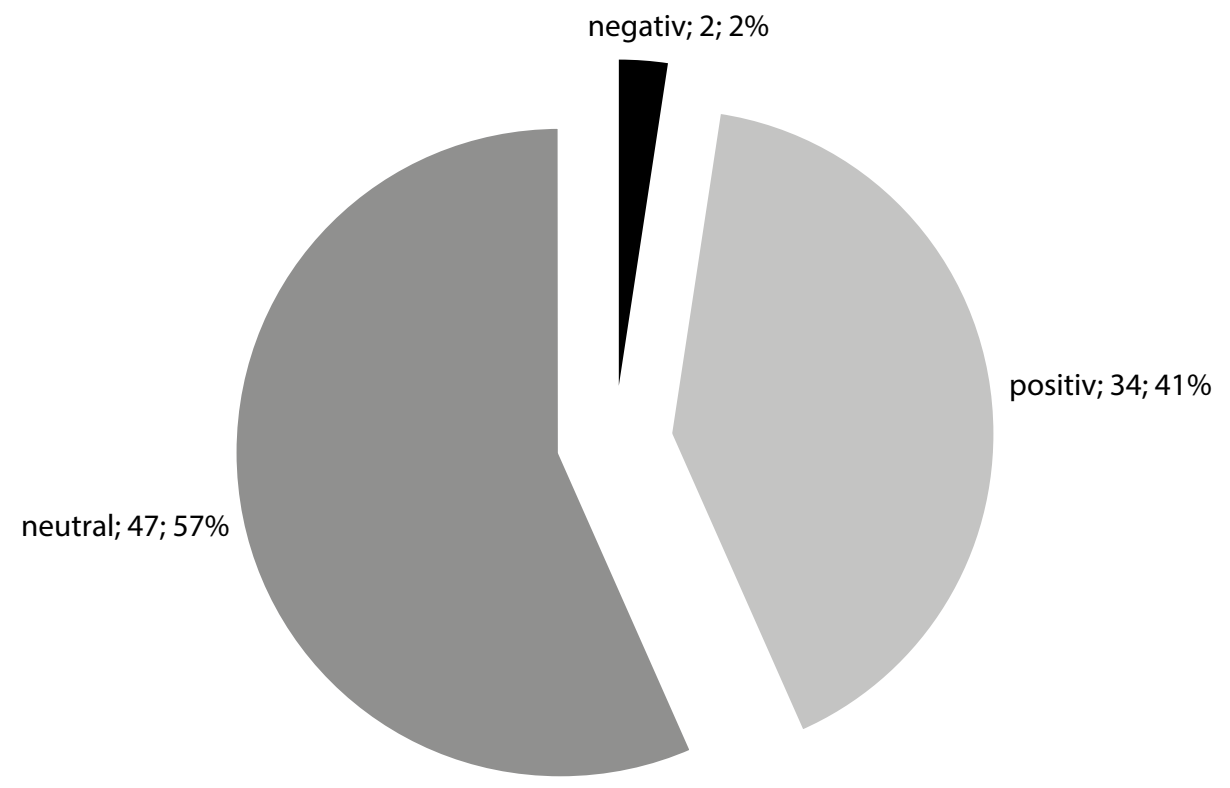

Diagramm Nr. 3. Anzahl der Publikationen zum Thema des Besuchs von Papst Franziskus in Kuba und in Mexiko in den polnischen Portalen nach der Veröffentlichungsart, $\mathrm{N}=83$

Quelle: Newspoint

Der Anteil an negativen, positiven und neutralen Nachrichten war unter den analysierten Portalen vergleichbar. Negative Nachrichten bezüglich des Papstes und der Pilgerreise sind in den folgenden Portalen erschienen: www.wp.pl und www.gazeta.pl.

Die meisten geforschten Internetportale bedienen sich der Mitteilungen aus den Diensten PAP, KAI und RAI. Vor dem päpstlichen Besuch erschien eine Publikation mit negativer Aussage und sie betraf das Gespräch von Papst Franziskus mit Kyrill I. Es wurde die Äußerung des Vorstehers der griechisch-katholischen Kirche Erzbischof Światosław Szewczuk veröffentlicht. Eine andere kritische Aussage waren die Worte des Präsidentschaftskandidaten der Vereinigten Staaten von Amerika Donald Trump, der für eine Kriegsentscheidung des Konflikts mit ISIS sprach ${ }^{13}$. Materialien, die die Aussage und den Inhalt der päpstlichen Reden

${ }^{13}$ Siehe [ohne Autor], Ukraina. Abp Szewczuk: spotkanie Franciszka z Cyrylem nie przyniesie istotnych zmian, 06.02.2016, in: http://wiadomosci.gazeta.pl/wiadomosci/1,114877, 19591496,ukraina-abp-szewczuk-spotkanie-franciszka-z-cyrylem-nie-przyniesie.html, 


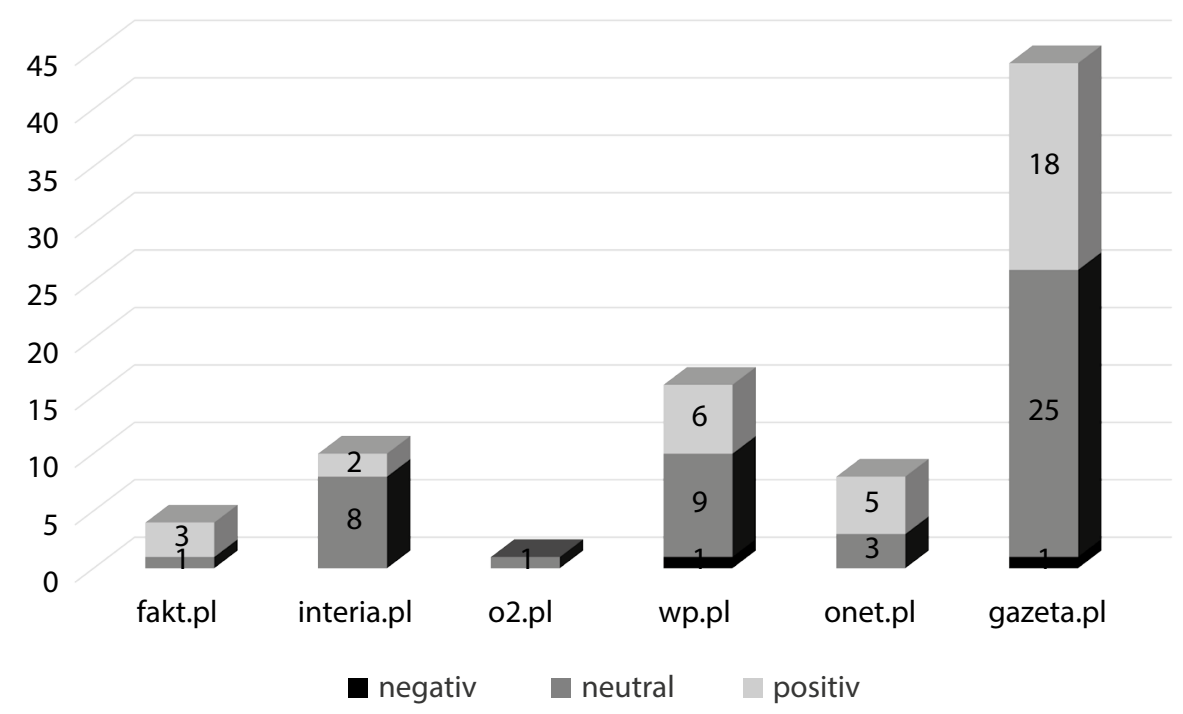

Diagramm Nr. 4. Anzahl der Publikationen zum Thema des Besuchs von Papst Franziskus in Kuba und in Mexiko in den polnischen Portalen nach der Veröffentlichungsort und -art, $\mathrm{N}=83$

Quelle: Newspoint

vertieften, wurden nicht veröffentlicht. Am Tag des apostolischen Besuchs wurden lediglich Agenturnachrichten mit einzelnen publizistischen Kommentaren veröffentlicht, indem man sich auf soziale Fragen (Emigranten, Kampf gegen Kartelle, Missverhältnisse zwischen den Armen und den Reichen) sowie auf den ökumenischen Dialog konzentrierte ${ }^{14}$.

[Zugriff 15.03.2018]; [ohne Autor], Donald Trump: papież zechce mnie jako prezydenta USA, gdy IS zaatakuje Watykan, 18.02.2016, in: http://wiadomosci.wp.pl/kat,1356,wid,18170791,martykul.html, [Zugriff 15.03.2018].

${ }^{14}$ Siehe [ohne Autor], Historyczne spotkanie papieża z patriarchq moskiewskim, 11.02.2016, in: http://fakty.interia.pl/swiat/news-historyczne-spotkanie-papieza-zpatriarcha-moskiewskim,nId,2143675, [Zugriff 15.03.2018]; [ohne Autor], Franciszek i Cyryl: niech Europa będzie wierna chrześcijańskim korzeniom, 12.02.2016, in: http://wiadomosci. gazeta.pl/wiadomosci/1,114871,19621038,franciszek-i-cyryl-niech-europa-bedzie-wierna-chrzescijanskim.html, [Zugriff 15.03.2018]; [ohne Autor], Papież w Meksyku. Mówił o korupcji, przemocy, handlu narkotykami, 12.02.2016, in: http://wiadomosci.onet.pl/swiat/papiezw-meksyku-mowil-o-korupcji-przemocy-handlu-narkotykami/mrmfc0, [Zugriff 15.03.2018]; [ohne Autor], Papież w szpitalu w Meksyku, 18.02.2016, in: http://www.fakt.pl/swiat/papiez-franciszek-w-szpitalu-w-meksyky,artykuly,611128.html, [Zugriff 15.03.2018]; [ohne Autor], Meksyk. Papież prosi Indian o przebaczenie za krzywdy, których doznali, 15.02.2016, 


\subsection{April 2016 - Griechenland}

Die eintägige apostolische Reise von Papst Franziskus nach Griechenland fand am 16. April 2016 statt und umfasste die Insel Lesbos. Während der Pilgerreise traf sich der Papst mit den Flüchtlingen im Lager. Mit Premier von Griechenland Alexis Tsipras sowie mit Bartholomäus I. (Patriarch von Konstantinopel), mit Erzbischof von Athen Hieronymos II. und dem Vorsitzenden der Bischofskonferenz von Griechenland Frangiskos Papamanolis unterschrieb der Papst eine Erklärung über die Hilfe den Flüchtlingen. In der Lehre konzentrierte er sich ebenfalls auf die Hilfe den Flüchtlingen.

In den analysierten Portalen wurden 35 Texte zum Thema dieses Besuchs veröffentlicht. Der erste war die Nachricht vom 5. April 2016 im Portal www. interia.pl. Es war eine Ankündigung der geplanten Pilgerreise nach Lesbos. Der Autor informiert über ihre Einmaligkeit sowie auch über die Entscheidung bezüglich der Reise, die im letzten Moment getroffen wurde ${ }^{15}$. Die letzte Publikation erschien am 18. April 2016 im Portal www.gazeta.pl. Im Text wurde die praktische Hilfe von Papst Franziskus zugunsten der Flüchtlinge und das Hinbringen von ein paar Familien nach Rom betont, wo sie die Möglichkeit des Aufenthalts in italienischen Pfarreien erhielten ${ }^{16}$. Die mit der Pilgerreise verbundenen Berichte wurden am Tag des Besuchs bzw. ein Tag später veröffentlicht. Aufgrund der Entscheidung des Papstes bezüglich der Reise nach Lesbos, die erst vor ein paar Tagen getroffen wurde, waren umfangreichere Presseankündigungen der geplanten Pilgerreise nicht möglich. Es waren am häufigsten Pressemitteilungen veröffentlicht (24). Es gab 16 veröffentlichte Nachrichten in der Zeit vor der päpstlichen

in: http://wiadomosci.gazeta.pl/wiadomosci/1,114877,19630578,meksyk-papiez-prosi-indian-o-przebaczenie-za-krzywdy-ktorych.html, [Zugriff 15.03.2018]; [ohne Autor], Meksyk. Papież: nie popadać w rezygnację w obliczu gangów i przemocy, 16.02.2016, in: http:// wiadomosci.gazeta.pl/wiadomosci/1,114877,19636172,meksyk-papiez-nie-popadac-w-rezygnacje-w-obliczu-gangow-i-przemocy.html, [Zugriff 15.03.2018]; [ohne Autor], Papież zakończył wizytę w Meksyku i wraca do Rzymu, 18.02.2016, in: http://wiadomosci.gazeta.pl/ wiadomosci/1,114871,19642683, papiez-zakonczyl-wizyte-w-meksyku-i-wraca-do-rzymu. html, [Zugriff 15.03.2018].

${ }^{15}$ Siehe [ohne Autor], Papież spotka się z uchodźcami na Lesbos, 05.04.2016, in: http:// fakty.interia.pl/raporty/raport-nowy-papiez/aktualnosci/news-papiez-spotka-sie-zuchodzcami-na-lesbos,nId,2174931, [Zugriff 15.03.2018].

${ }^{16}$ Siehe T. Bielecki, Papież zabiera uchodźców, 18.04.2016, in: http://wyborcza. pl/1,75399,19934589, papiez-zabiera-uchodzcow.html?disableRedirects=true, [Zugriff 15.03. 2018]. 


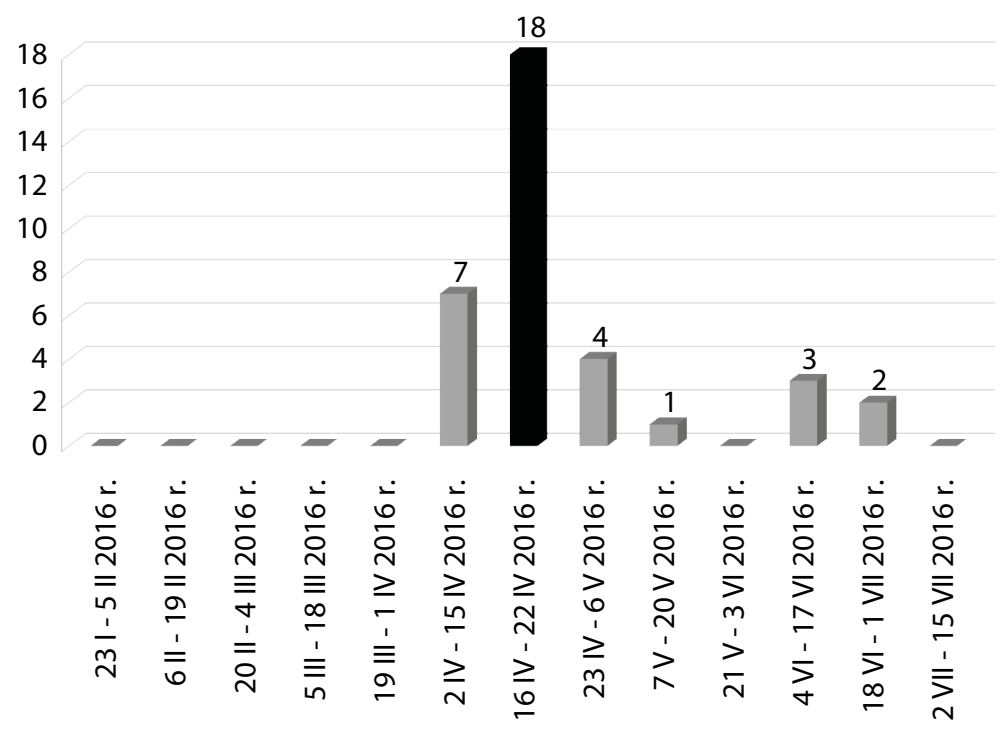

Diagramm Nr. 5. Anzahl der Publikationen zum Thema des Besuchs von Papst Franziskus in Griechenland in den polnischen Portalen nach dem Veröffentlichungstag, $\mathrm{N}=35$

Quelle: Newspoint

apostolischen Reise und 14 danach. Die letzte davon wurde vier Tage nach ihrer Beendigung veröffentlicht.

Die meisten Nachrichten zum Thema der päpstlichen Pilgerreise nach Griechenland veröffentlichte das Portal www.interia.pl (13), was ihm rund 37\% des Anteils am Markt der Internetnachrichten zu diesem Thema ausmacht. Die weiteren Portale unter Berücksichtigung der Publikationsanzahl waren entsprechend: www.onet.pl (11), www.wp.pl (6) und www.gazeta.pl (3). Wenig Informationen zum analysierten Thema veröffentlichte www.fakt.pl (2) und keine www.o2.pl (0).

Weitere Stufe der auszuführenden Forschungen war Ermittlung der Kommunikationsweise über diese apostolische Pilgerreise von Papst Franziskus. Aus den durchgeführten Forschungen geht es hervor, dass 8/9 der veröffentlichten Nachrichten positiv (4) bzw. neutral waren (29). Es gab 2 negative Kommentare und sie betrafen die Furcht vor Immigranten und der Reaktion auf die Entscheidung des Papstes, Migranten nach Rom hinzubringen.

Der Anteil an negativen, positiven und neutralen Nachrichten war unter den analysierten Portalen vergleichbar. Negative Nachrichten bezüglich des Papstes 


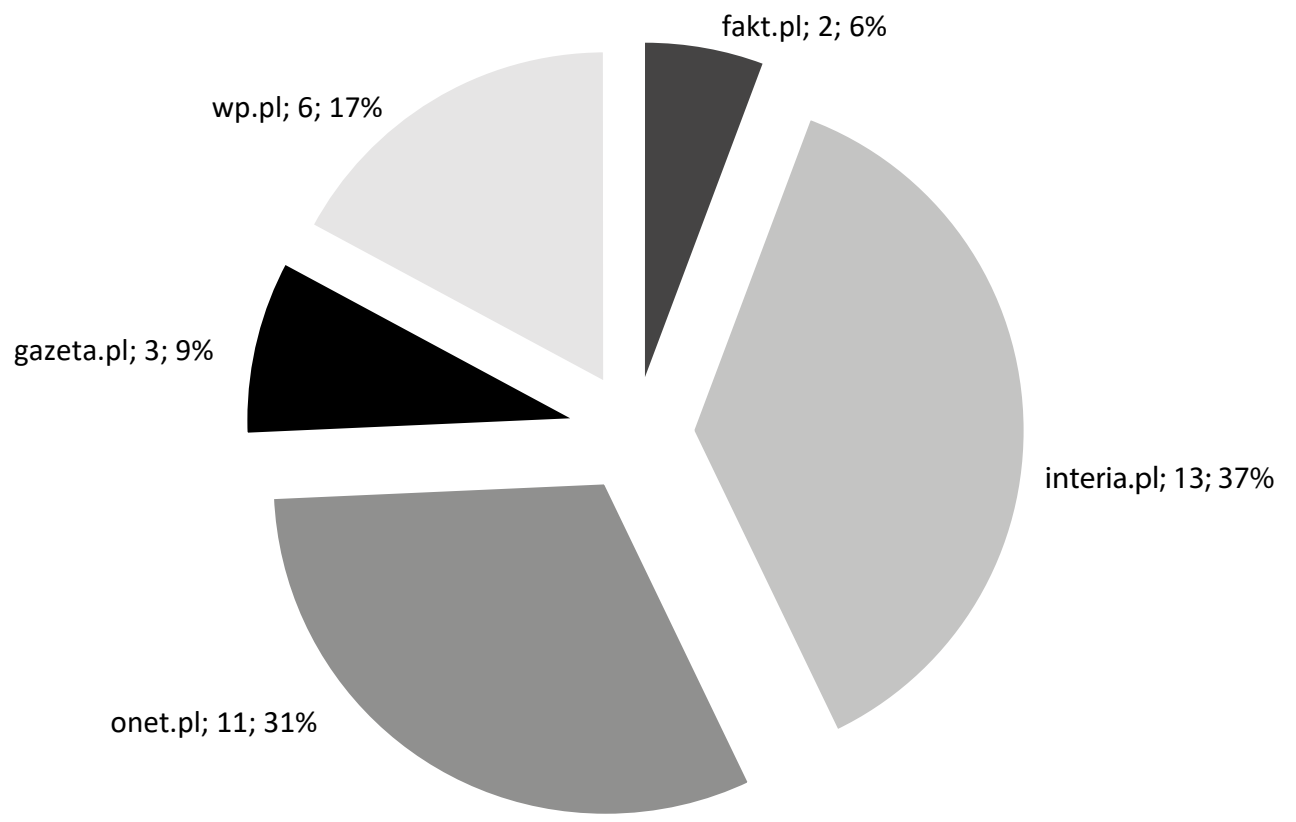

Diagramm Nr. 6. Anzahl der Publikationen zum Thema des Besuchs von Papst Franziskus in Griechenland in den polnischen Portalen nach dem Veröffentlichungstag, N=35 Quelle: Newspoint

neutral; $29,83 \%$

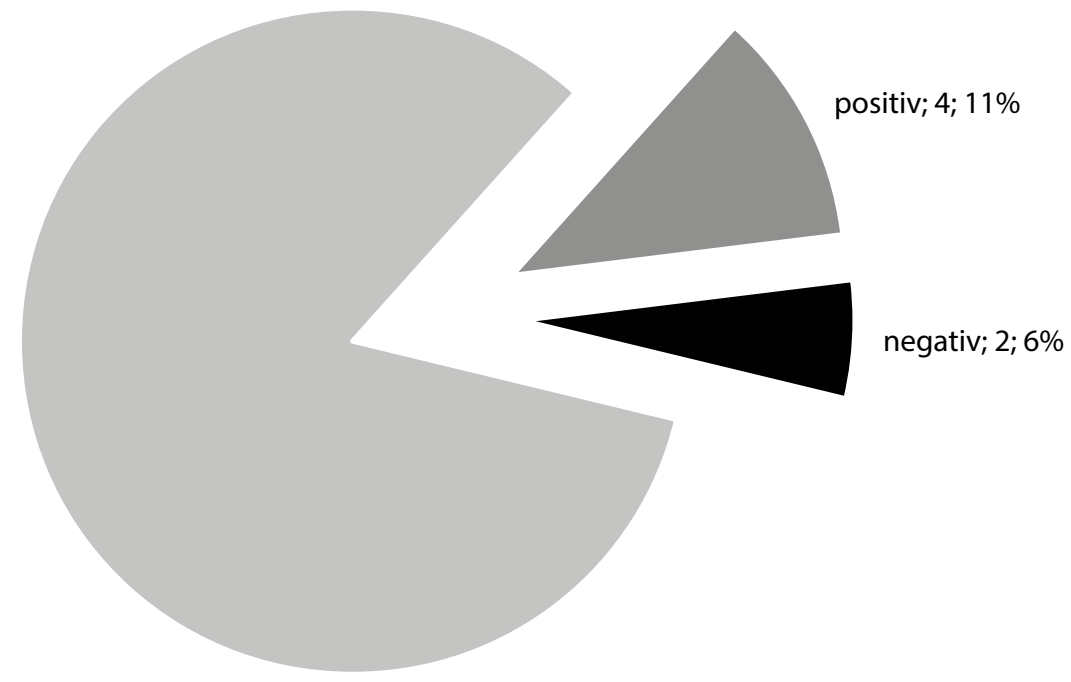

Diagramm Nr. 7. Anzahl der Publikationen zum Thema des Besuchs von Papst Franziskus in Griechenland in den polnischen Portalen nach der Veröffentlichungsart, N=35 Quelle: Newspoint

$$
\text { KULTURA - MEDIA - TEOLOGIA 38/2019 }
$$




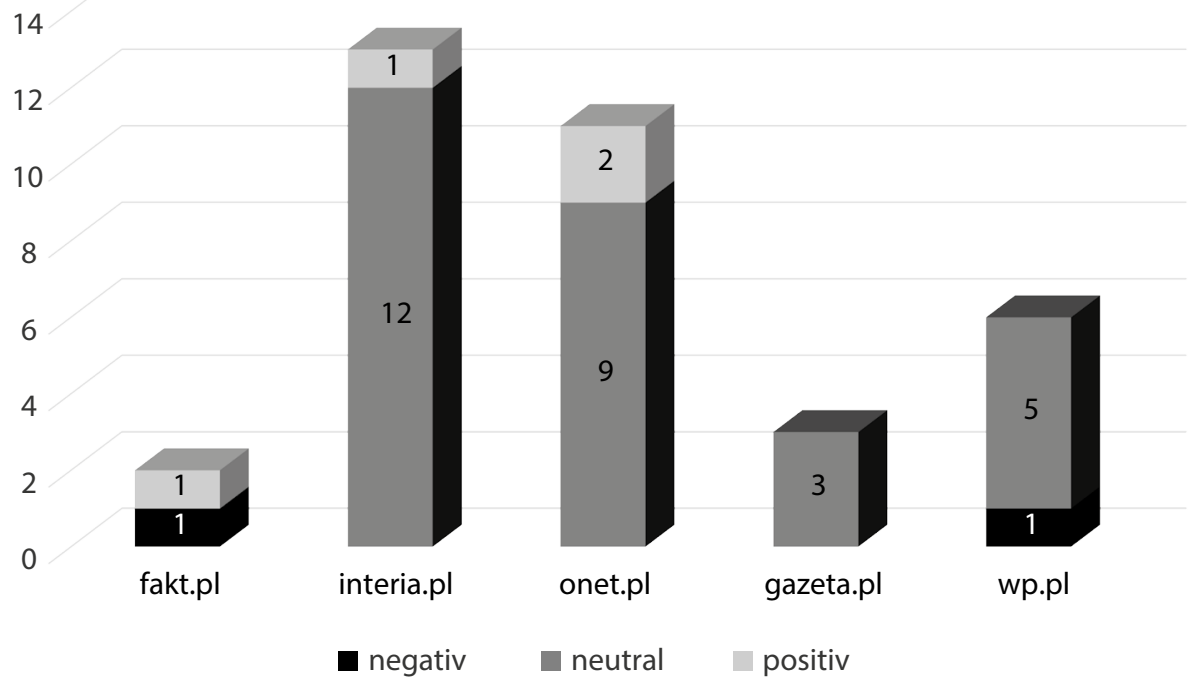

Diagramm Nr. 8. Anzahl der Publikationen zum Thema des Besuchs von Papst Franziskus in Griechenland in den polnischen Portalen nach dem Veröffentlichungsort und -art, $\mathrm{N}=35$

Quelle: Newspoint

und der Pilgerreise sind in den folgenden Portalen erschienen: www.wp.pl und www.fakt.pl.

Die meisten geforschten Internetportale bedienen sich der Mitteilungen aus den Diensten PAP, KAI und RAI. Vor der päpstlichen Pilgerreise zum Flüchtlingsund Migrantenlager sind wenige Materialien aufgrund der Benachrichtigung darüber erst ein paar Tage davor erschienen. Negative Texte Negative Texte betrafen das Hinbringen von Flüchtlingen nach Rom durch den Papst an Bord des Flugzeugs. Pastor Paweł Chojecki sprach über Verstoß des Papstes gegen die Migrationsvorschriften. Ähnlich schrieb in seinem Kommentar Paweł Lisicki ${ }^{17}$. Materialien, die die Aussage und den Inhalt der päpstlichen Reden vertieften, wurden nicht veröffentlicht. Am Tag des apostolischen Besuchs wurden lediglich Agenturnachrichten mit einzelnen publizistischen Kommentaren veröffentlicht, indem

${ }^{17}$ Siehe [ohne Autor], Duchowny: Kara śmierci dla Tuska? To zasadne, 18.04.2016, in: http://www.fakt.pl/polska/papiez-zlamal-prawo-a-dla-tuska-kara-smierci,artykuly,626830. html, [Zugriff 01.03.2016]; P. Lisicki, Dla papieża Franciszka licza się tylko dokumenty, 18.04.2016, in: http://wiadomosci.wp.pl/kat,1356,wid,18170791,martykul.html, [Zugriff 15.03.2018]. 
man sich auf soziale Fragen (Emigranten, Immigranten) konzentrierte. Es wurde auf die Notwendigkeit der Systemlösungen diesbezüglich hingewiesen. Die polnischen Geistlichen und Pfarreien wurden zum Nachahmen des Papstes bezüglich der Offenheit gegenüber den Vertriebenen ermuntert ${ }^{18}$.

\subsection{4.-.26 Juni 2016 - Armenien}

Die apostolische Reise von Papst Franziskus nach Armenien fand von 24. bis zum 26. Juni 2016 statt und verlief unter dem Motto „Besuch im ersten christlichen Land“. Die vierzehnte Auslandsreise von Franziskus bestand im Aufenthalt in vier Ortschaften: Etschmiadsin, Jerewan, Giumri und Chor Wirap. Während des Aufenthalts von Papst Franziskus in diesem Land wurden zwei Symbole des armenischen Volkes betont: der Berg Ararat, auf dem laut der Tradition die Arche Noah nach der Sintflut anhielt, und das Kloster in Chor Wirap, wo hl. Gregor der Erleuchter, Gründer und Patron der Armenischen Apostolischen Kirche 15 Jahre lang gefangen gehalten wurde. Während seiner Pilgerreise traf sich der Papst mit dem Katholikos Armeniens und appellierte auch um Frieden, insbesondere im Zusammenhang mit dem Völkermord der Armenier durch die Türken am Anfang des 20. Jahrhunderts.

In den analysierten Portalen wurden 20 Texte zum Thema dieses Besuchs veröffentlicht. Der erste war die Nachricht vom 9. April 2016 im Portal www. interia.pl. Es war eine Ankündigung der geplanten Pilgerreise nach Armenien. Man kündigte an, der Bischof von Rom Armenien ein Jahr nach der Gedenkfeier des hundertsten Jahrestages des Blutbades von tausenden Armeniern durch die türkischen Truppen. Das Blutbad von Armeniern im Jahre 1915 war der erste

${ }^{18}$ Siehe [ohne Autor], Papież spotka się z uchodźcami: widziałem tyle bólu, 17.04.2016, in: http://wiadomosci.wp.pl/kat,1356,title,Papiez-po-spotkaniu-z-uchodzcami-widzialemtyle-bolu,wid,18274373,wiadomosc.html, [Zugriff 15.03.2018]. T. Cylka, Polscy biskupi w cieniu papieża Franciszka. Czy każda parafia przyjmie jednq rodzinę?, 18.04.2016, in: http://gazeta.pl/1,75398,19934458,polscy-biskupi-w-cieniu-papieza-franciszka-czy-kazda-parafia. html, [Zugriff 15.03.2018]; [ohne Autor], Grecja: starcia w obozie dla migrantów na Lesbos, 26.04.2016, in: http://wiadomosci.onet.pl/swiat/grecja-starcia-w-obozie-dla-migrantowna-lesbos/3j3zny, [Zugriff 15.03.2018]; [ohne Autor], Mini szczyt o Europie, 06.05.2016, in: http://fakty.interia.pl/swiat/news-miniszczyt-o-europie-w-zwiazku-z-nagroda-karolawielkiego-dl,nId,2197551, [Zugriff 15.03.2018]; [ohne Autor], Niezwykłe gesty papieża Franciszka: normalność jako styl pontyfikatu, 26.05.2016, in: http://wiadomosci.onet.pl/swiat/ niezwykle-gesty-papieza-franciszka-normalnosc-jako-styl-pontyfikatu/09yzx6, [Zugriff 15.03.2018]. 
Völkermord im 20. Jahrhundert ${ }^{19}$. Die letzte Publikation erschien am 22. April 2016 im Portal www.onet.pl. Jakub Biedrzyński weist auf die Worte von Papst Franziskus hin, die er an homosexuelle Personen betreffen den Respekt für sie im Zusammenhang mit den Aussagen mancher Publizisten richtete. Diese Worte sagte er während seiner Rückkehr nach Vatikan aus ${ }^{20}$. Die mit der Pilgerreise verbundenen Berichte wurden am Tag des Besuchs bzw. ein Tag später veröffentlicht. Sie betrafen am meisten die päpstliche Lehre über den Frieden als auch die Kommentare zum Thema des Völkermordes der Armenier. Es waren am häufigsten Pressemitteilungen veröffentlicht (14). Es gab 4 veröffentlichte Nachrichten in der Zeit vor der päpstlichen apostolischen Reise und 7 danach. Die letzte davon wurde ein Monat nach ihrer Beendigung veröffentlicht und knüpfte an die Worte des römischen Bischofs an.

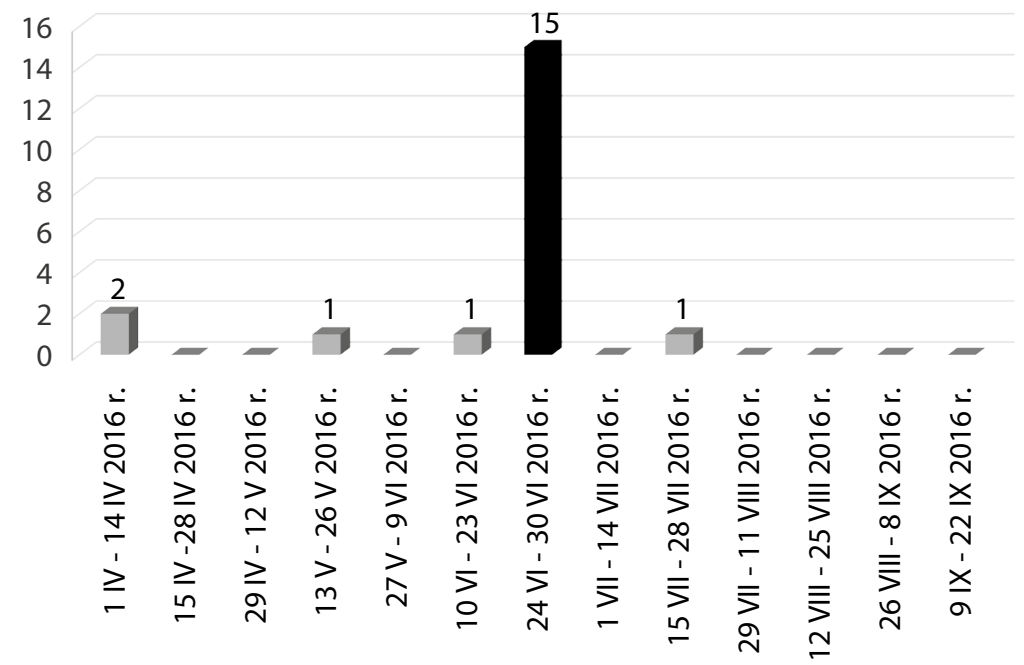

Diagramm Nr. 9. Anzahl der Publikationen zum Thema des Besuchs von Papst Franziskus in Armenien in den polnischen Portalen nach dem Veröffentlichungstag, $\mathrm{N}=20$

Quelle: Newspoint

${ }^{19}$ Siehe [ohne Autor], Papież Franciszek odwiedzi Armenię, Gruzję i Azerbejdżan, 09.04.2016, in: http://fakty.interia.pl/swiat/news-papiez-franciszek-odwiedzi-armenie-gruzje-i-azerbejdzan,nId,2182479, [Zugriff 15.03.2018].

${ }^{20}$ Siehe J. Biedrzycki, Auto-homoterroryzm prawicy, 22.06.2016, in: http://wiadomosci. onet.pl/kraj/auto-homoterroryzm-prawicy/4gsx8h, [Zugriff 15.03.2018]. 
Die meisten Nachrichten zum Thema der päpstlichen Pilgerreise nach Armenien veröffentlichte das Portal www.onet.pl (8), was ihm rund 40\% des Anteils am Markt der Internetnachrichten zu diesem Thema ausmacht. Die weiteren Portale unter Berücksichtigung der Publikationsanzahl waren entsprechend: www. wp.pl (7), www.interia.pl (4) und www.fakt.pl (1). Über die Pilgerreise gibt es keine Informationen in den Portalen www.gazeta.pl (0) sowie www.o2.pl (0). Im Falle des Portals www.gazeta.pl erschienen Nachrichten während der Pilgerreise. Derzeit sind sie nicht mehr im Portal verfügbar.

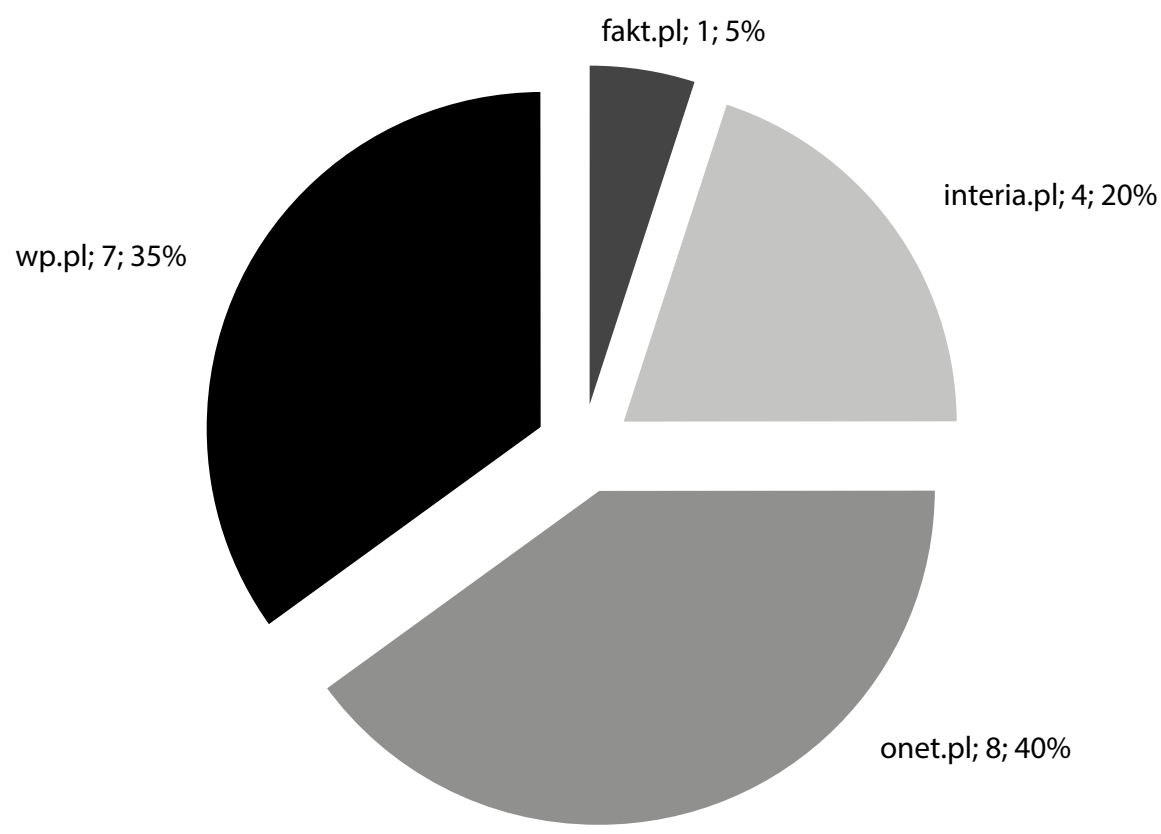

Diagramm Nr. 10. Anzahl der Publikationen zum Thema des Besuchs von Papst Franziskus in Armenien in den polnischen Portalen nach dem Veröffentlichungsort, $\mathrm{N}=20$

Quelle: Newspoint

Weitere Stufe der auszuführenden Forschungen war Ermittlung der Kommunikationsweise über diese apostolische Pilgerreise von Papst Franziskus. Aus den durchgeführten Forschungen geht es hervor, dass 19/20 der veröffentlichten Nachrichten positiv (2) bzw. neutral waren (17). Es gab 1 negativen Kommentar und er betraf nicht das Hauptthema der Pilgerreise, sondern der Nichtanpassung, nach dem Autor, der Kirche in Polen an die Lehre von Papst Franziskus. 
neutral; $17 ; 85 \%$

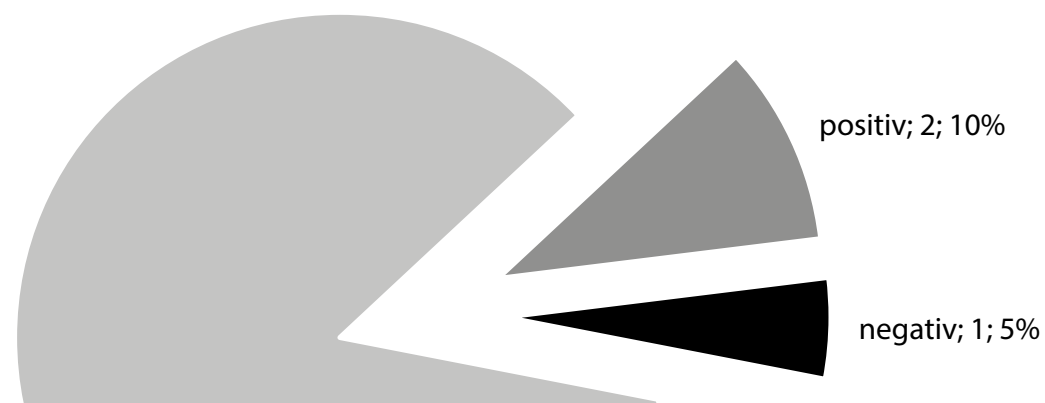

Diagramm Nr. 11. Anzahl der Publikationen zum Thema des Besuchs von Papst Franziskus in Armenien in den polnischen Portalen nach der Veröffentlichungsart, N=20

Quelle: Newspoint

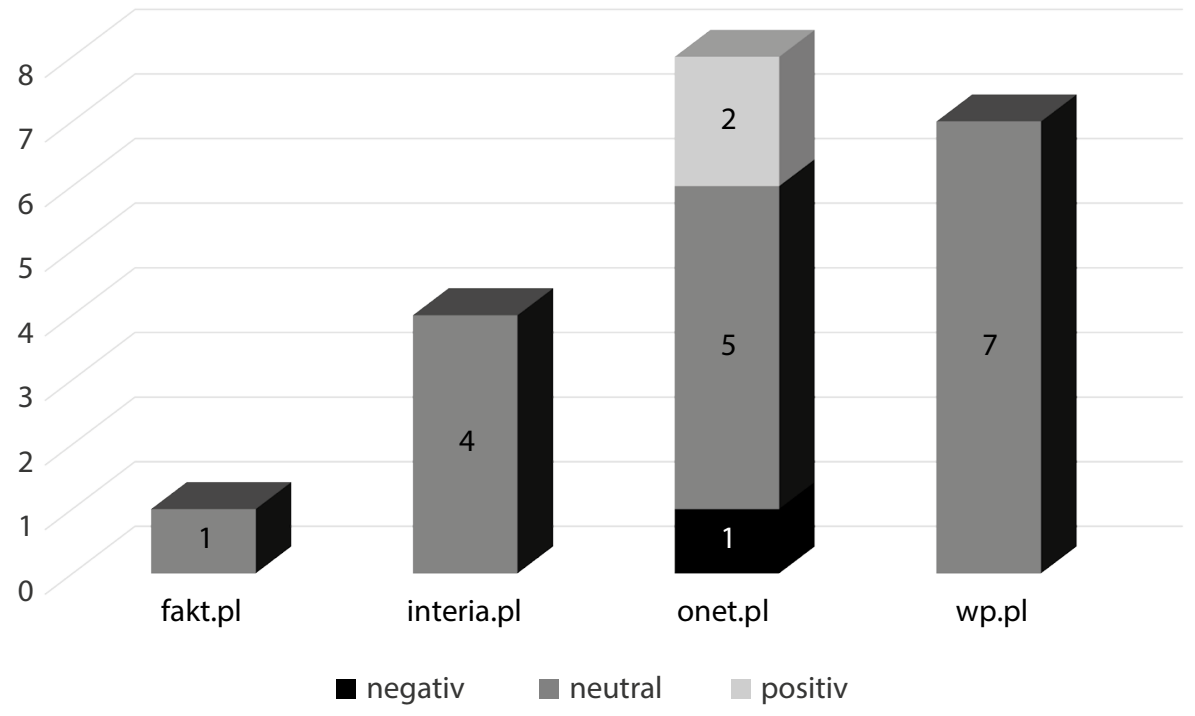

Diagramm Nr. 12. Anzahl der Publikationen zum Thema des Besuchs von Papst Franziskus in Armenien in den polnischen Portalen nach dem Veröffentlichungsort und -art, $\mathrm{N}=20$

Quelle: Newspoint 
Der Anteil an negativen, positiven und neutralen Nachrichten war unter den analysierten Portalen vergleichbar. Negative und positive Nachrichten erschienen im Portal www.onet.pl.

Die meisten geforschten Internetportale bedienen sich der Mitteilungen aus den Diensten PAP, KAI und RAI, ohne ihre eigenen Korrespondenten zu senden. Somit ist die Aussage der veröffentlichten Inhalte am meisten neutral. Die die Pilgerreise ansagenden Texte konzentrierten sich vor allem auf die Frage des Völkermordes der Armenier und das Gespräch mit dem Katholikos Armeniens. Negativer Text betraf, nach dem Autor, keine Einführung der päpstlichen Lehre bezüglich der Homosexualität in der Kirche in Polen. Die Äußerung des Papstes zu diesem Thema war kein Hauptthema der Lehre während der Pilgerreise ${ }^{21}$. Materialien, die die Aussage und den Inhalt der päpstlichen Reden vertieften, wurden nicht veröffentlicht. Am Tag des apostolischen Besuchs wurden lediglich Agenturnachrichten mit einzelnen publizistischen Kommentaren veröffentlicht, indem man sich auf soziale Fragen (Emigranten, Immigranten) konzentrierte. Es wurde auf die Notwendigkeit der Systemlösungen diesbezüglich hingewiesen. Die polnischen Geistlichen und Pfarreien wurden zum Nachahmen des Papstes bezüglich der Offenheit gegenüber den Vertriebenen ermuntert ${ }^{22}$.

\subsection{7.-31. Juli 2016 - Polen}

Die apostolische Reise von Papst Franziskus nach Polen fand von 27. bis zum 31. Juli 2016 statt. Die Reise des Bischofs von Rom galt drei Städten: Kraków, Częstochowa und Oświęcim. Das Reiseziel war insbesondere das Treffen mit der katholischen Jugend aus der ganzen Welt während des. 31. Weltjugendtages in Krakau. Franziskus war der dritte Papst, der Polen besuchte; früher besuchte Papst Johannes Paul II neunmal seine Heimat (1979, 1983, 1987, zweimal 1991,

${ }^{21}$ Siehe J. Biedrzycki, Auto-homoterroryzm prawicy, 22.06.2016, in: http://wiadomosci. onet.pl/kraj/auto-homoterroryzm-prawicy/4gsx8h, [Zugriff 15.03.2018].

${ }^{22}$ Siehe [ohne Autor], Papież nazwał rzeź Ormian ludobójstwem, 27.06.2016, in: http:// wiadomosci.onet.pl/swiat/papiez-nazwal-rzez-ormian-ludobojstwem/99s695, [Zugriff 15.03.2018]; [ohne Autor], Watykan odrzuca tureckq krytykę słów papieża o ludobójstwie Ormian, 27.06.2016, in: http://wiadomosci.wp.pl/kat,1356,title,Watykan-odrzuca-turecka-krytyke-slow-papieza-o-ludobojstwie-Ormian,wid,18397036,wiadomosc.html, [Zugriff 15.03.2018]; M. Makowski, Polka za murami Watykanu. Niezwykłe życie u boku dwóch papieży, 28.06.2016, in: http://kobieta.onet.pl/dziecko/wychowanie/polka-za-murami-watykanuniezwykle-zycie-u-boku-dwoch-papiezy/kh85pj, [Zugriff 15.03.2018]. 
Marcin Wrzos, Apostolische Auslandsreisen von Papst Franziskus, darunter Missionsreisen...

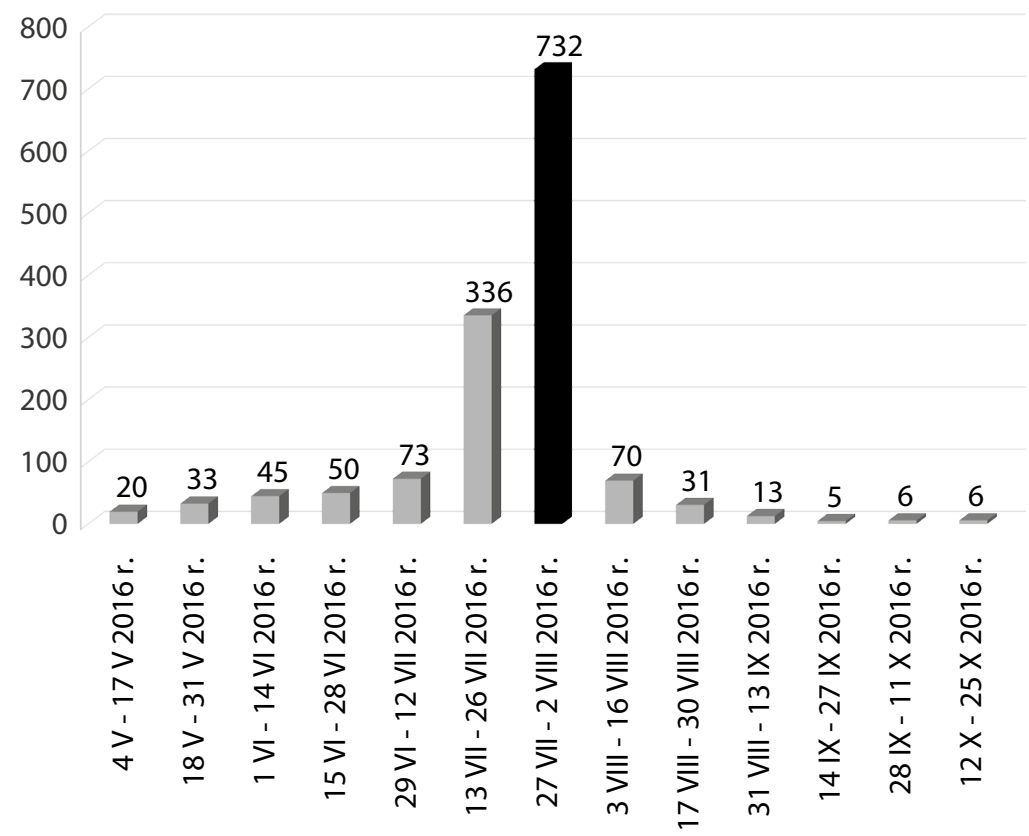

Diagramm Nr. 13. Anzahl der Publikationen zum Thema des Besuchs von Papst Franziskus in Polen in den polnischen Portalen nach dem Veröffentlichungstag, $\mathrm{N}=1420$

Quelle: Newspoint

1995, 1997, 1999 und 2002) und einmal Benedikt XVI. (2006). Es war der elfte Besuch des amtierenden römisch-katholischen Kirchenvorstehers in Polen und der erste von Franziskus.

In den analysierten Portalen wurden 1420 Texte zum Thema dieses Besuchs veröffentlicht. Weil wir die Zeit von drei Monaten vor und nach dem päpstlichen Besuch forschen, umfassen die Forschungen keine früheren und späteren Veröffentlichungen, was bei der analysierten Pilgerreise der Fall war. Die Pilgerreise nach Polen selbst kann ein separater Beitrag zu ausfeilten theologischen und zeitungswissenschaftlichen Forschungen bilden. Die erste Publikation in der analysierten Zeit erschien am 29. April 2016 im Portal www.wp.pl. Es war eine Nachricht bezüglich der Gewährleistung der Sicherheit für die zum Weltjugendtag nach Krakau kommenden Pilgern ${ }^{23}$. Die letzte Publikation in der analysierten Zeit

${ }^{23}$ Siehe [ohne Autor], ŚDM w Polsce. Porozumienie wojewodów ws. zabezpieczenia wizyty papieża, 29.04.2016, in: http://wiadomosci.wp.pl/kat,1019409,wid,18297897,martykul. html, [Zugriff 15.03.2018]. 
erschien am 22. Oktober 2016 im Portal www.onet.pl. Es betrifft die Annahmen für die pastorale Arbeit mit der Jugend nach WJT ${ }^{24}$. Die mit der Pilgerreise verbundenen Berichte wurden während ihrer Dauer und auch davor sowie danach veröffentlicht. Sie waren mit WJT selbst, jedoch auch mit den logistischen Vorbereitungen sowie und der Zusammenfassung von WJT verbunden. Es waren am häufigsten Pressemitteilungen veröffentlicht (986). Es gab 1116 veröffentlichte Nachrichten in der Zeit vor der päpstlichen apostolischen Reise (WJT selbst begann 5 Tage vor Beginn der päpstlichen Pilgerreise) und 235 danach. Die letzte der analysierten Publikationen wurde drei Monate nach ihrer Beendigung veröffentlicht.

Die meisten Nachrichten zum Thema der päpstlichen Pilgerreise nach Polen veröffentlichte das Portal www.onet.pl (637), was ihm rund 44\% des Anteils am Markt der Internetnachrichten ausmacht. Die weiteren Portale unter Berücksichtigung der Publikationsanzahl waren entsprechend: www.interia.pl (331), www. wp.pl (280), www.fakt.pl (142), www.gazeta.pl (24) sowie www.o2.pl (14). Im Falle des Portals www.gazeta.pl erschienen Nachrichten während der Pilgerreise. Derzeit sind sie nicht mehr im Portal verfügbar.

Weitere Stufe der auszuführenden Forschungen war Ermittlung der Kommunikationsweise über diese apostolische Pilgerreise von Papst Franziskus. Aus den durchgeführten Forschungen geht es hervor, dass 99/100 der veröffentlichten Nachrichten positiv (43) bzw. neutral waren (1376). Es gab 9 negative Kommentare und sie betrafen nicht das Hauptthema der Pilgerreise, sondern Ordnungsund Finanzangelegenheiten, der päpstlichen Lehre über die Flüchtlinge oder unbegründete Kritik der Politiker ${ }^{25}$.

${ }^{24}$ Siehe [ohne Autor], Rozpoczyna się cykl spotkań dla młodych po ŚDM, 24.10.2016, in: http://krakow.onet.pl/rozpoczyna-sie-cykl-spotkan-dla-mlodych-po-sdm/k7g65c, [Zugriff 15. 03.2018].

${ }^{25}$ Zob. K. Surówka, Skandal w Krakowie. Zniszczyli baner ŚDM wart 5 tysięcy, 07.06.2016, in: http://www.fakt.pl/wydarzenia/polska/krakow/skandal-w-krakowie-zniszczylibaner-sdm-wart-5-tysiecy/0r70t2f, [Zugriff 15.03.2018]; [ohne autor], Szokujqce słowa Rokity o papieżu. Dlaczego drwi?, 28.07.2016, in: http://www.fakt.pl/www.fakt.pl/wydarzenia/polityka/szokujace-slowa-jana-rokity-o-papiezu-franciszku/pm5mz56, [Zugriff 15.03.2018]; [ohne Autor], Skandal! Poseł atakuje papieża!, 28.07.2016, in: http:// www.fakt.pl/www.fakt.pl/wydarzenia/polityka/robert-winnicki-atakuje-papiezafranciszka-ws-uchodzcow/ytwmzst, [Zugriff 15.03.2018]; J. Matlak, Opole: po hucznym świętowaniu $w$ ramach ŚDM zostały śmieci, 29.07.2016, in: http://wiadomosci.onet.pl/ 
Marcin Wrzos, Apostolische Auslandsreisen von Papst Franziskus, darunter Missionsreisen...

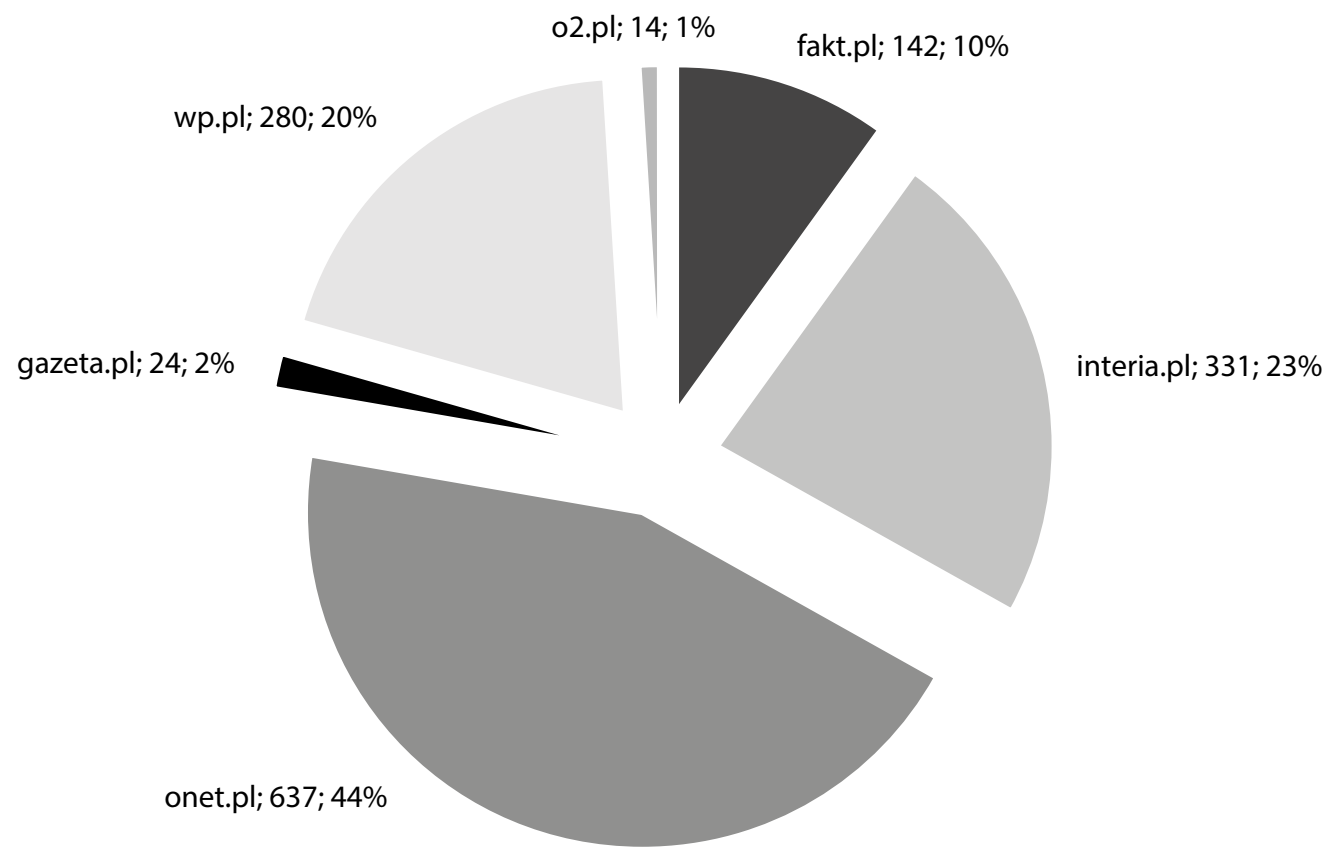

Diagramm Nr. 14. Anzahl der Publikationen zum Thema des Besuchs von Papst Franziskus in Polen in den polnischen Portalen nach dem Veröffentlichungsort, N=1420 Quelle: Newspoint

neutral; 1376; 96\%

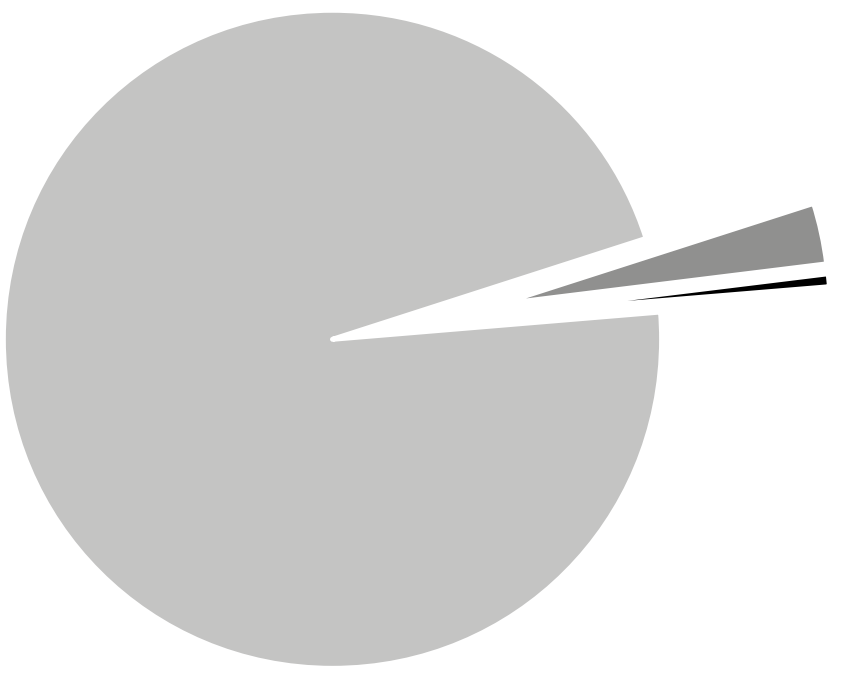

positiv; $43 ; 3 \%$ negativ; $9 ; 1 \%$

Diagramm Nr. 15. Anzahl der Publikationen zum Thema des Besuchs von Papst Franziskus in Polen in den polnischen Portalen nach der Veröffentlichungsart, N=1420 Quelle: Newspoint

$$
\text { KULTURA - MEDIA - TEOLOGIA 38/2019 }
$$


Der Anteil an negativen, positiven und neutralen Nachrichten war unter den Portalen www.onet.pl, www.interia.pl, www.wp.pl und www.gazeta.pl vergleichbar. Hingegen waren die Verhältnisse der negativen Nachrichten gegenüber den positiven und neutralen schlechter in den Portalen www.fakt.pl i www.o2.pl.

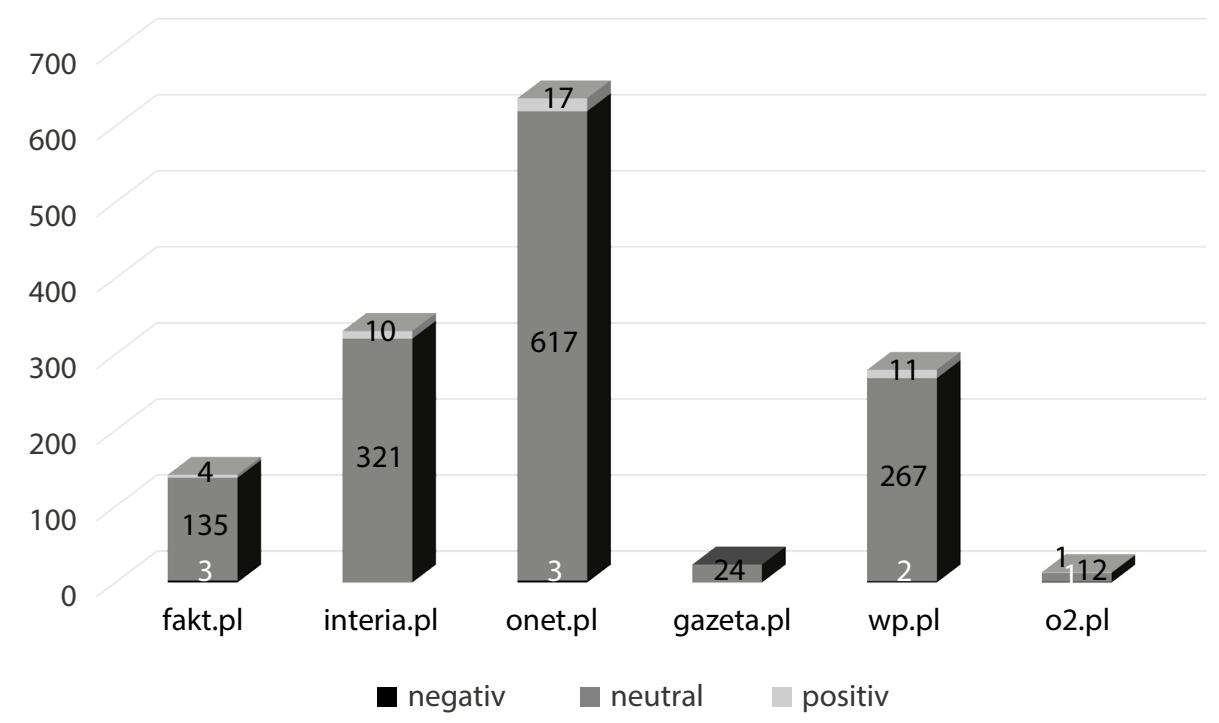

Diagramm Nr. 16. Anzahl der Publikationen zum Thema des Besuchs von Papst Franziskus in Polen in den polnischen Portalen nach dem Veröffentlichungsort und -art, $\mathrm{N}=1420$

Quelle: Newspoint

Die meisten geforschten Internetportale bedienen sich der Mitteilungen aus den Diensten PAP, KAI und RAI, deshalb sind viele Publikationen neutral, nicht emotional geladen trotz der Tatsache, dass jede der Redaktionen ihren Vertreter

opole/opole-po-hucznym-swietowaniu-w-ramach-sdm-zostaly-smieci/8byn1z, [Zugriff 15.03.2018]; [ohne Autor], W Brzegach jak po Woodstock. Zobacz, co zostawili pielgrzy$m i, 31.07 .2016$, in: https://www.o2.pl/galeria/w-brzegach-jak-po-woodstock-zobaczco-zostawili-pielgrzymi-6021028799083137g, [Zugriff 15.03.2018]; [ohne Autor], Sterty śmieci na terenie Campusu Misericordiae po ŚDM w Brzegach, 01.08.2016, in: http:// wiadomosci.onet.pl/krakow/sdm-2016-sterty-smieci-na-terenie-campusu-misericordiae-wbrzegach/5ec4cm, [Zugriff 15.03.2018]. 
Marcin Wrzos, Apostolische Auslandsreisen von Papst Franziskus, darunter Missionsreisen...

am WJT hatte. Die die Pilgerreise ansagenden Texte konzentrierten sich vor allem auf die logistischen Fragen und die Sicherheitsgewährleistung für Pilger ${ }^{26}$. Es ist auch eine Reihe von Materialien zur Zusammenfassung der Pilgerreise von Papst Franziskus als auch des Weltjugendtags in Krakau erschienen. Es wurde auf die Notwendigkeit der ausgefeilten Bildung der Jugend nach WJT, hingewiesen und man dankte dem Papst für seine kommunikative Sprache, die Evangelisierung betreffende Lehre und Offenheit gegenüber anderen. In den Texten wurde das Engagement der verschiedenen Dienste in die Sicherheitsgewährleistung für die Pilger betont, man bemerkte den Beitrag der Kirche zur Organisation des Ereignisses ${ }^{27}$.

${ }^{26}$ Siehe [ohne Autor], ŚDM w Polsce. Porozumienie wojewodów ws. zabezpieczenia wizyty papieża, 29.04.2016, in: http://wiadomosci.wp.pl/kat,1019409,wid,18297897,martykul. html, [Zugriff 15.03.2018].

${ }^{27}$ Siehe [ohne Autor], Prymas: papież pokazał chrześcijańskie miłosierdzie wobec uchodźcy, 01.08.2016, in: http://fakty.interia.pl/raporty/raport-swiatowe-dni-mlodziezy-krakow-2016/komentarze/news-prymas-papiez-pokazal-chrzescijanskie-milosierdziewobec-uch,nId,2244857, [Zugriff 15.03.2018]; [ohne Autor], Przesłanie papieża Franciszka po Światowych Dniach Młodzieży, 01.08.2016, in: http://wiadomosci.wp.pl/gid,18448829,kat,,title,Przeslanie-papieza-Franciszka-po-Swiatowych-Dniach-Mlodziezy,galeria.html, [Zugriff 15.03.2018]; [ohne Autor], Papież Franciszek wybrał najlepszego piłkarza, 01.08.2016, in: http://ofsajd.onet.pl/plotki/papiez-franciszek-wybral-najlepszego-pilkarza/hec1x8, [Zugriff 15.03.2018]; [ohne Autor], ŚDM: 300 tys. pielgrzymów wyjechało $w$ niedzielę pociq̨gami $z$ Krakowa, 01.08.2016, in: http://biznes.onet.pl/wiadomosci/kraj/sdm-300-tyspielgrzymow-wyjechalo-w-niedziele-pociagami-z-krakowa/zgtdnn, [Zugriff 15.03.2018]; [ohne Autor], Co warto wiedzieć o Panamie - następnym gospodarzu ŚDM?, 03.08.2016, in: http://wiadomosci.onet.pl/kraj/co-warto-wiedziec-o-panamie-nastepnym-gospodarzusdm/r7s56j, [Zugriff 15.03.2018]; [ohne Autor], Młodzieżowy język papieża, 03.08.2016, in: http://wiadomosci.wp.pl/gid,18449239,gpage,6,img,18449422,kat,1342,title,Zagraniczne-komentarze-po-wizycie-papieza-Franciszka-w-Polsce,galeria.html, [Zugriff 15.03.2018]; [ohne Autor], Witold Waszczykowski dla WP: gdyby Franciszek poruszył sprawę Smoleńska, to były olbrzymi sukces, 03.08.2016, in: http://wiadomosci.wp.pl/kat,1342,wid,18448911,martykul.html, [Zugriff 15.03.2018]; [ohne Autor], Abp Gądecki dziękuje prezydentowi Andrzejowi Dudzie za udział w ŚDM, 04.08.2016, in: http://wiadomosci.onet.pl/kraj/abp-gadeckidziekuje-prezydentowi-andrzejowi-dudzie-za-udzial-w-sdm/9nq4bq, [Zugriff 15.03.2018]; [ohne Autor], Listy gratulacyjne dla polskich służb, 06.08.2016, in: http://fakty.interia.pl/ raporty/raport-swiatowe-dni-mlodziezy-krakow-2016/aktualnosci/news-listy-gratulacyjnedla-polskich-sluzb-zabezpieczajacych-sdm-,nId,2247668, [Zugriff 15.03.2018]; A. Szczepańska, Narodowa pielgrzymka Polaków, 21.10.2016, in: http://fakty.interia.pl/religia/news-narodowa-pielgrzymka-polakow,nId,2294693, [Zugriff 15.03.2018]; [ohne Autor], Rozpoczyna się cykl spotkań dla młodych po ŚDM, 24.10.2016, in: http://krakow.onet.pl/rozpoczyna-sie-cykl-spotkan-dla-mlodych-po-sdm/k7g65c, [Zugriff 15.03.2018]. 


\subsection{September - 2. Oktober 2016 - Georgien, Aserbaidschan}

Die apostolische Reise von Papst Franziskus nach Georgien und Aserbaidschan fand vom 30. September bis zum 2. Oktober 2016 statt. Die sechszehnte apostolische Reise verlief unter den Mottos: „Wir alle sind Brüder“ (Aserbaidschan) sowie „Frieden euch“ (Georgien). Franziskus war der zweite Papst, der Georgien und Aserbaidschan besuchte. Früherer war Johannes Paul II, der Georgien 1999 und Aserbaidschan 2002 besuchte. Der Papst besuchte Tiflis und Mzcheta (Georgien) sowie Baku (Aserbaidschan). In der Pilgerreise wurden die Fragen der Ökumenismus und des Dialogs zwischen den Religionen besonders betont.

In den analysierten Portalen wurden 15 Texte zum Thema dieses Besuchs veröffentlicht. Der erste war die Nachricht vom 9. April 2016 im Portal www.interia.pl. Es war eine allgemeine Ankündigung von drei Pilgerreisen. Aufgrund der zeitlichen Entfernung wird sie in den geführten Forschungen nicht berücksichtigt $^{28}$. In den Medien schrieb man über die geplante Pilgerreise von Papst im Zusammenhang mit der Beerdigung des israelischen Premiers Schimon Peres, die während der päpstlichen Pilgerreise stattfinden sollte und dass sie aus diesem Grunde abgesagt werden sollte ${ }^{29}$. Die letzte Publikation erschien am 5. Oktober 2016 im Portal www.onet.pl. Es wurde die päpstliche Zusammenfassung der Pilgerreise veröffentlicht, die während der Generalaudienz in Rom verkündigt worden war. Der Papst sagte, dass Georgien und Aserbaidschan sehr alte, historische, Kultur- und Religionswurzeln haben, er betonte, dass die eine neue Phase erleben: Beide Länder feiern dieses Jahr 25. Jahrestag der Unabhängigkeit, nachdem sie den meisten Teil des 20. Jahrhunderts unter dem sowjetischen Regime verbrachten. Und sie treffen in der Phase auf Schwierigkeiten ${ }^{30}$. Die mit der Pilgerreise verbundenen Berichte wurden am Tag des Besuchs bzw. ein Tag später veröffentlicht. Sie betrafen am meisten die päpstliche Lehre über den Frieden, den ökumenischen Dialog und unter den Religionen, als auch die Kommentare

${ }^{28}$ Siehe [ohne Autor], Papież Franciszek odwiedzi Armenię, Gruzję i Azerbejdżan, 09.04.2016, in: http://fakty.interia.pl/swiat/news-papiez-franciszek-odwiedzi-armeniegruzje-i-azerbejdzan,nId,2182479, [Zugriff 15.03.2018].

${ }^{29}$ Siehe [ohne Autor], Simon Peres nie żyje. Papież Franciszek nie pojedzie na pogrzeb, 28.10.2016, in: http://fakty.interia.pl/swiat/news-szimon-peres-nie-zyje-papiez-franciszeknie-pojedzie-na-pogr,nId,2281901, [Zugriff 15.03.2018].

${ }^{30}$ Siehe [ohne Autor], Papież: starałem się wesprzeć narody Gruzji i Azerbejdżanu, 05.10.2016, in: http://wiadomosci.onet.pl/swiat/papiez-staralem-sie-wesprzec-narodygruzji-i-azerbejdzanu/pkc6wt, [Zugriff 15.03.2018]. 
betreffend die heutige Situation der Armenier und der Georgier. Es waren am häufigsten Pressemitteilungen veröffentlicht (13). Es wurden 2 Nachrichten in der Zeit vor der päpstlichen apostolischen Reise und 4 danach veröffentlicht. Die letzte davon wurde zwei Tage nach ihrer Beendigung veröffentlicht.

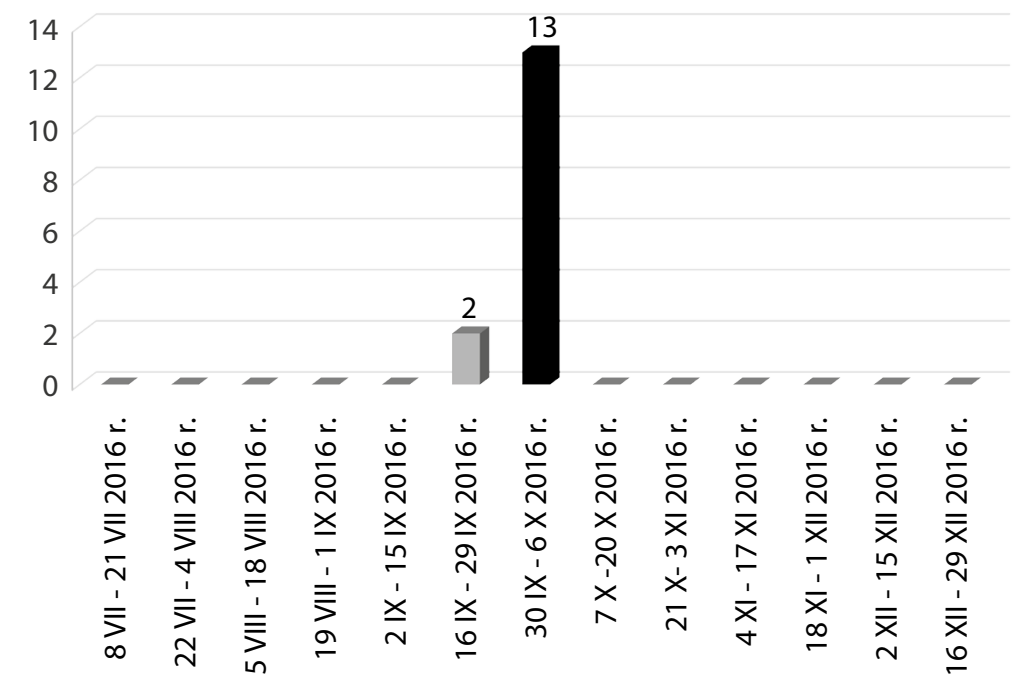

Diagramm Nr. 17. Anzahl der Publikationen zum Thema des Besuchs von Papst Franziskus in Georgien und Aserbaidschan in den polnischen Portalen nach dem Veröffentlichungstag, $\mathrm{N}=15$ Quelle: Newspoint

Die meisten Nachrichten zum Thema der päpstlichen Pilgerreise nach Armenien veröffentlichte das Portal www.interia.pl (6), was ihm rund 40\% des Anteils am Markt der Internetnachrichten ausmacht. Die weiteren Portale unter Berücksichtigung der Publikationsanzahl waren entsprechend: www.onet.pl (5) sowie www.wp.pl (4). Über die Pilgerreise wurden keine Informationen in den Portalen www.gazeta.pl (0), www.fakt.pl (0) sowie www.o2.pl (0) veröffentlicht. Im Falle des Portals www.gazeta.pl erschienen Nachrichten während der Pilgerreise. Derzeit sind sie nicht mehr verfügbar.

Weitere Stufe der auszuführenden Forschungen war Ermittlung der Kommunikationsweise über diese apostolische Pilgerreise von Papst Franziskus. Aus den durchgeführten Forschungen geht es hervor, dass alle veröffentlichten 


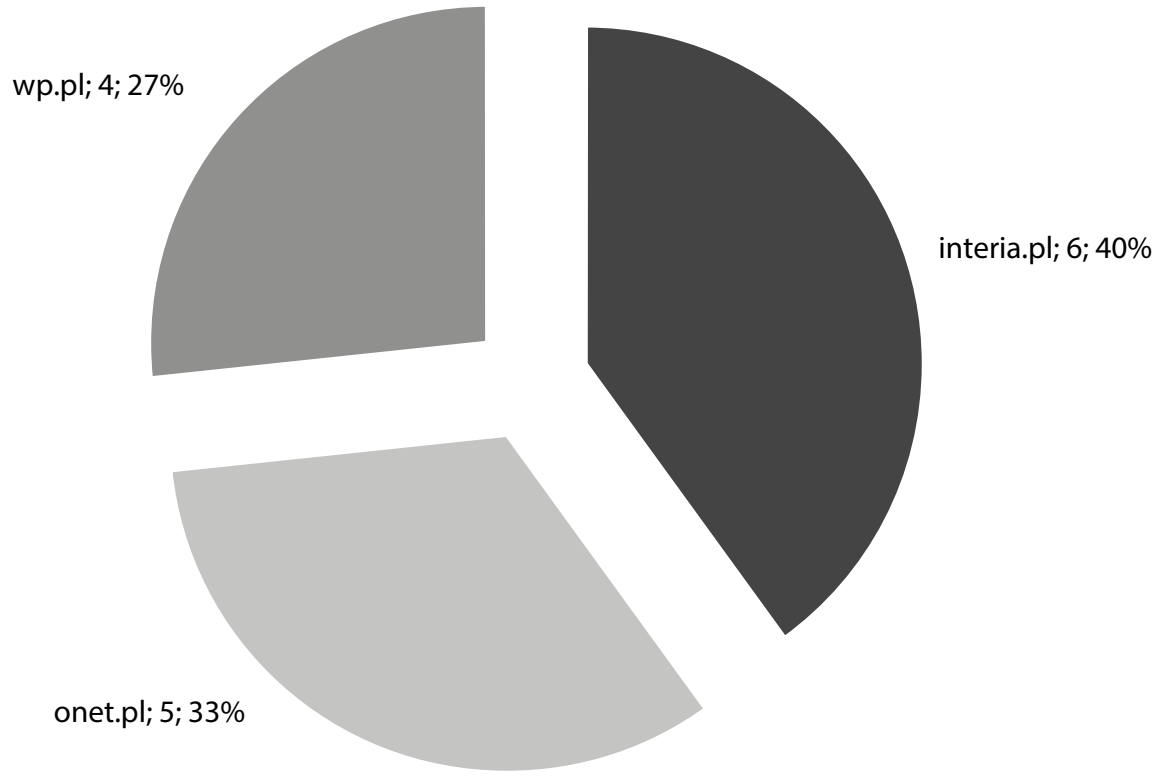

Diagramm Nr. 18. Anzahl der Publikationen zum Thema des Besuchs von Papst Franziskus in Georgien und Aserbaidschan in den polnischen Portalen nach dem Veröffentlichungsort, $\mathrm{N}=15$

Quelle: Newspoint

neutral; $15 ; 100 \%$

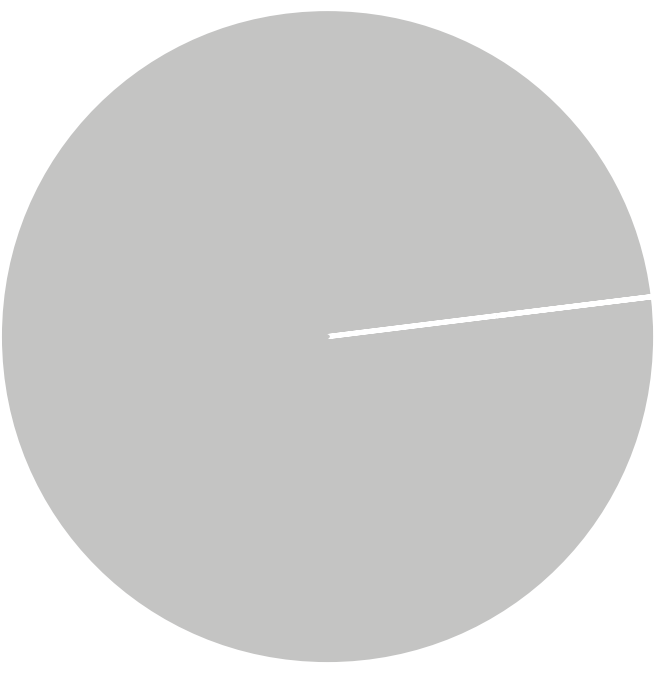

Diagramm Nr. 19. Anzahl der Publikationen zum Thema des Besuchs von Papst Franziskus in Georgien und Aserbaidschan in den polnischen Portalen nach der Veröffentlichungsart, N=15 Quelle: Newspoint

\section{KULTURA - MEDIA - TEOLOGIA 38/2019}




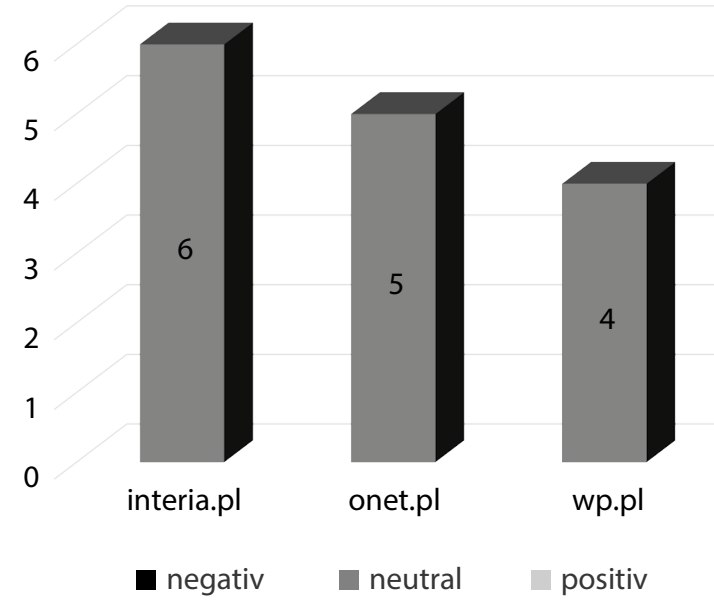

Diagramm Nr. 20. Anzahl der Publikationen zum Thema des Besuchs von Papst Franziskus in Georgien und Aserbaidschan in den polnischen Portalen nach dem Veröffentlichungsort und -art, N=15 Quelle: Newspoint

Nachrichten neutral waren. Es resultierte davon, dass Agenturmitteilungen in den Portalen veröffentlicht wurden.

Das Zahlenverhältnis der positiven und negativen zum Thema der besprochenen Pilgerreise veröffentlichten Nachrichten ist aufgrund dessen, dass es lediglich neutrale Nachrichten waren, identisch.

Die meisten geforschten Internetportale bedienen sich der Mitteilungen aus den Diensten PAP, KAI, RV und RAI, ohne ihre eigenen Korrespondenten zu senden. Somit ist die Aussage der veröffentlichten Inhalte neutral, denn es sind Nachdrücke der Agenturmitteilungen. Die die Pilgerreise ansagenden Texte konzentrierten sich vor allem auf die Tatsache des Unabhängigkeitsjahrestages und auch der wirtschaftlichen Umwandlungen, die nicht immer auf ethische Weise durchgeführt wurden. Man wies auf den Druck seitens Israels die Pilgerreise im Zusammenhang mit der Beerdigung des Premiers Schimon Peres abzusagen hin ${ }^{31}$. Mate-

${ }^{31}$ Siehe [ohne Autor], Papież Franciszek odwiedzi Armenię, Gruzję i Azerbejdżan, 09.04.2016, in: http://fakty.interia.pl/swiat/news-papiez-franciszek-odwiedzi-armeniegruzje-i-azerbejdzan,nId,2182479, [Zugriff 15.03.2018]; [ohne Autor], Simon Peres nie żyje. Papież Franciszek nie pojedzie na pogrzeb, 28.10.2016, in: http://fakty.interia.pl/swiat/ news-szimon-peres-nie-zyje-papiez-franciszek-nie-pojedzie-na-pogr,nId,2281901, [Zugriff 15.03.2018]. 
rialien, die die Aussage und den Inhalt der päpstlichen Reden vertieften, wurden nicht veröffentlicht. Georgien hat ein Problem mit Russland, Aserbaidschan ist ein Land ohne offene Grenzen, hat Probleme mit Aserbaidschan - so definierte der Bischof von Rom die politischen Probleme der besuchten Länder. Er sprach auch über die mit ihrer Entwicklung zusammenhängenden Probleme. Der letzte die Pilgerreise betreffende Artikel erschien in den analysierten Portalen vier Tage nach ihrer Beendigung ${ }^{32}$.

\subsection{Oktober - 1. November 2016 - Schweden}

Am 25. Januar 2016 erklärte Vatikan, dass Papst Franziskus eine apostolische Reise nach Schweden macht, um an Eröffnungsfeier des 500. Jahrestages der Reformation teilzunehmen. Am 31. Oktober fand in Lund eine katholisch-lutherische Zeremonie statt, organisiert gemeinsam durch die Lutherische Kirche Schwedens und die katholische Diözese von Stockholm. Der Gottesdienst basierte auf dem liturgischen Führer „Gemeinsames Gebet", der vom Lutherischen Weltbund und vom Päpstlichen Rat zur Förderung der Einheit der Christen bearbeitet wurde. Die Feierlichkeiten förderten den Versöhnungsprozess zwischen den Lutheranern und den Katholiken. Zwei Tage später las Papst Franziskus heilige Messe auf dem Stadion Swedbank in Malmö.

In den analysierten Portalen wurden 10 Texte zum Thema dieses Besuchs veröffentlicht. Der erste war die Nachricht vom 9. September 2016 im Portal www.onet.pl. Es war eine Ankündigung der geplanten Pilgerreise nach Schweden zum Jubiläum des 500. Jahrestages der Reformation. Es wurde ein detaillierter Plan des zweitägigen Besuchs dargestellt ${ }^{33}$. Die letzte Publikation erschien am 18. November 2016, auch im Portal www.onet.pl. Sie beschreibt die Kritik der Konservativen für den Pontifikat von Papst Franziskus. Unter den am meisten

${ }^{32}$ Siehe [ohne Autor], Franciszek komentuje nie wypełnienie testamentu Jana Pawła II, 03.10.2016, in: http://wiadomosci.wp.pl/kat,9972,wid,18527783,martykul.html, [Zugriff 15.03.2018]; S. Wysocka, Gruzja ma problem z Rosja, 05.10.2016, in: http://fakty.interia.pl/ religia/news-franciszek-o-homoseksualistach-towarzyszylem-im-i-nigdy-nie-,nId,2284267, [Zugriff 15.03.2018]; [ohne Autor], Papież: starałem się wesprzeć narody Gruzji i Azerbejdża$n u, 05.10 .2016$, in: http://wiadomosci.onet.pl/swiat/papiez-staralem-sie-wesprzec-narodygruzji-i-azerbejdzanu/pkc6wt, [Zugriff 15.03.2018].

${ }^{33}$ Siehe [ohne Autor], Watykan ogłosił program wizyty papieża w Szwecji, 09.09.2016, in: http://wiadomosci.onet.pl/swiat/watykan-oglosil-program-wizyty-papieza-w-szwecji/ hsr7tk, [Zugriff 15.03.2018]. 


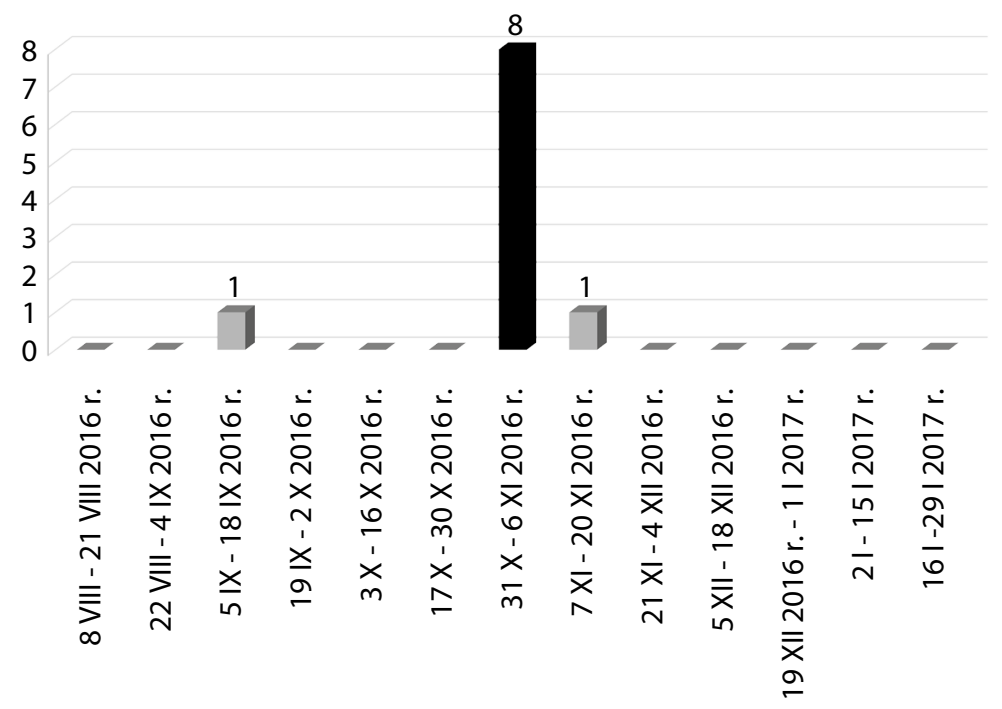

Diagramm Nr. 21. Anzahl der Publikationen zum Thema des Besuchs von Papst Franziskus in Schweden in den polnischen Portalen nach dem Veröffentlichungstag, $\mathrm{N}=10$

Quelle: Newspoint

kontroversen Punkten wies man aufs Feiern des Jahrestages der Kirchenspaltung in Schweden auf ${ }^{34}$. Die mit der Pilgerreise verbundenen Berichte wurden während ihrer Dauer veröffentlicht. Sie betrafen am meisten die päpstliche Lehre zum Thema des Ökumenismus. Es wurden am häufigsten Pressemitteilungen veröffentlicht (9). Es wurden 1 Nachricht vor der päpstlichen apostolischen Reise und auch 1 danach veröffentlicht. Die letzte davon wurde ein Monat nach ihrer Beendigung veröffentlicht und knüpfte an den Pontifikat des Bischofs von Rom an.

Die meisten Nachrichten zum Thema der päpstlichen Pilgerreise nach Schweden veröffentlichte das Portal www.interia.pl (5), was ihm rund 50\% des Anteils am Markt der Internetnachrichten ausmacht. Die weiteren Portale unter Berücksichtigung der Publikationsanzahl waren entsprechend: www.onet.pl (3) und www.wp.pl (2). Über die Pilgerreise gibt es keine Informationen in den Portalen www.gazeta.pl (0), www.fakt.pl (0) sowie www.o2.pl (0). Im Falle des

${ }^{34}$ Siehe [ohne Autor], Papież: Kościół to nie drużyna piłkarska, która zabiega o kibiców, 18.11.2016, in: http://wiadomosci.onet.pl/kraj/auto-homoterroryzm-prawicy/4gsx8h, [Zugriff 15.03.2018]. 

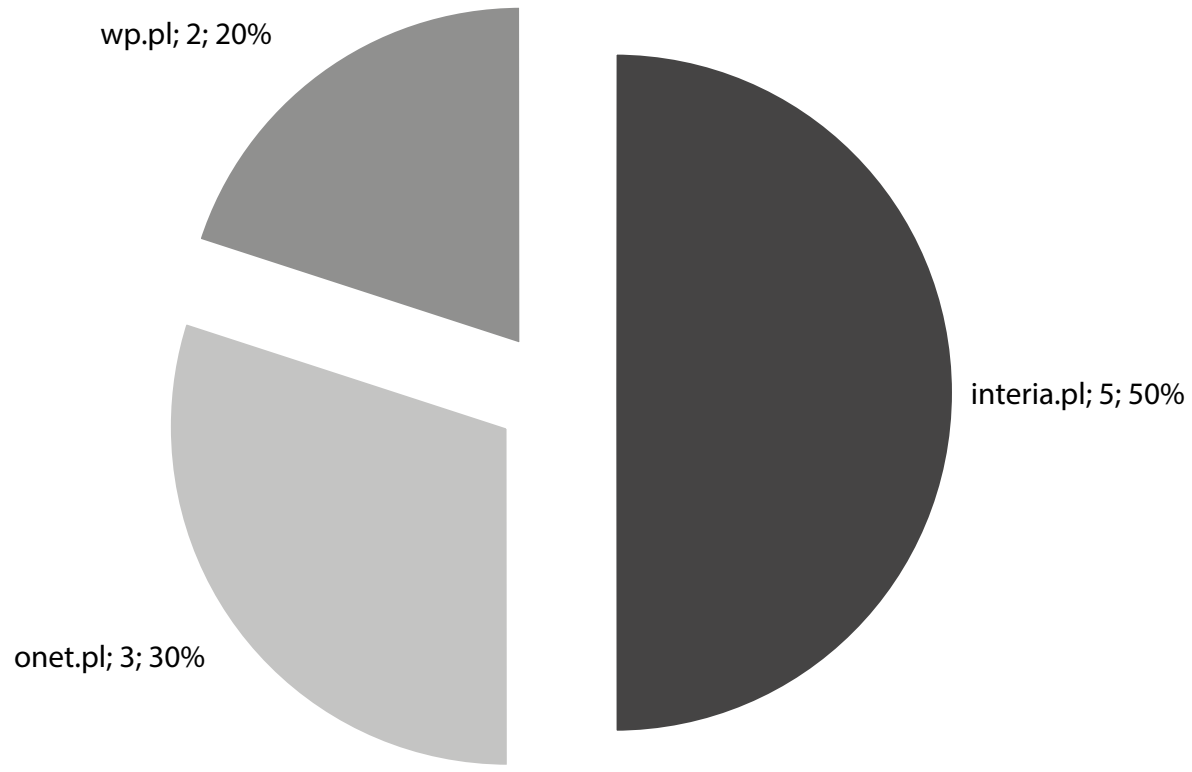

Diagramm Nr. 22. Anzahl der Publikationen zum Thema des Besuchs von Papst Franziskus in Schweden in den polnischen Portalen nach dem Veröffentlichungsort, $\mathrm{N}=10$

Quelle: Newspoint

neutral; $10 ; 100 \%$

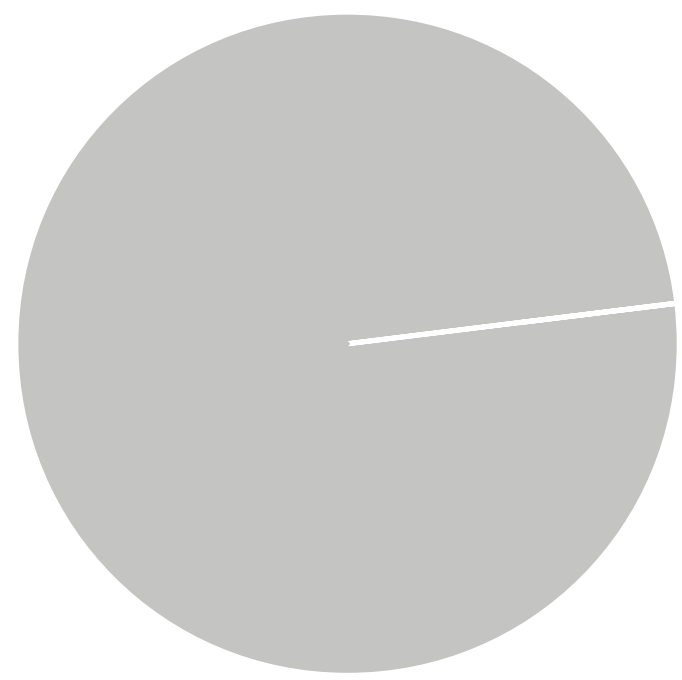

Diagramm Nr. 23. Anzahl der Publikationen zum Thema des Besuchs von Papst Franziskus in Schweden in den polnischen Portalen nach der Veröffentlichungsart, $\mathrm{N}=10$

Quelle: Newspoint

\section{KULTURA - MEDIA - TEOLOGIA 38/2019}


Portals www.gazeta.pl erschienen Nachrichten während der Pilgerreise. Derzeit sind sie nicht mehr im Portal verfügbar.

Weitere Stufe der auszuführenden Forschungen war Ermittlung der Kommunikationsweise über diese apostolische Pilgerreise von Papst Franziskus. Aus den durchgeführten Forschungen geht es hervor, dass 10/10, somit alle Publikationen neutral waren, was auf ihr Agenturcharakter zurückzuführen ist.

Das Zahlenverhältnis der positiven und negativen zum Thema dieser Pilgerreise veröffentlichten Nachrichten ist aufgrund dessen, dass es lediglich neutrale Nachrichten waren, identisch.

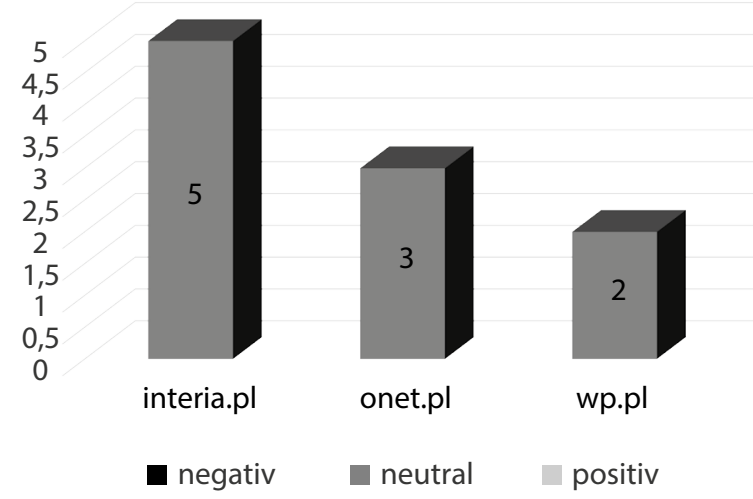

Diagramm Nr. 24. Anzahl der Publikationen zum Thema des Besuchs von Papst Franziskus in Schweden in den polnischen Portalen nach dem Veröffentlichungsort und -art, $\mathrm{N}=10$ Quelle: Newspoint

Die meisten geforschten Internetportale bedienen sich der Mitteilungen aus den Diensten PAP, KAI, RAI, ggf. RV, ohne ihre eigenen Korrespondenten zu senden. Somit ist die Aussage der veröffentlichten Inhalte am meisten neutral, es gibt keine ausgefeilten, publizistischen Analysen darunter. In den die Pilgerreise von Franziskus ansagenden Texten konzentrierte man sich auf die ökumenischen Inhalte und die Reformation ${ }^{35}$. Materialien, die die Aussage und den Inhalt der

${ }^{35}$ Siehe [ohne Autor], Watykan ogłosił program wizyty papieża w Szwecji, 09.09.2016, in:vhttp://wiadomosci.onet.pl/swiat/watykan-oglosil-program-wizyty-papieza-w-szwecji/ hsr7tk, [Zugriff 15.03.2018]. 
päpstlichen Reden vertieften, wurden nicht veröffentlicht. 8/10 der Texte wurden während der päpstlichen Pilgerreise und einer danach veröffentlicht. Er enthielt den Pontifikat von Franziskus zusammenfassende Inhalte ${ }^{36}$.

\section{THEOLOGISCHE ANALYSE DER VERÖFFENTLICHTEN INHALTE}

Die meisten Nachrichten bezüglich der päpstlichen Pilgereisen waren Agenturnachrichten, am häufigsten nach der Katholischen Informationsagentur (KAI), der Polnischen Nachrichtenagentur (PAP) und der Rundfunkinformationsagentur (RAI) veröffentlicht. Ihre Anzahl beträgt 1099 von 1580, was 69,6\% der gesamten Informationen darstellt. Es sind Inhalte, die ohne Angabe des Autors und dupliziert veröffentlicht werden. Die gleiche Nachricht erscheint in mehreren Internetportalen. Die Nachrichtenagenturen konzentrieren sich fast ausschließlich auf neutrale Nachrichten und auf päpstliche Pilgerreisen werden keine dedizierten Journalisten entsandt. Dies geschieht aus finanziellen Gründen und auch wegen keinem größeren Interesse für die Pilgerreisen. Kontroverse Nachrichten sind jedoch Domäne der Portale mit Charakter einer Boulevardzeitung, somit bei den analysierten Portalen sind das: www.fakt.pl sowie www.o2.pl. Die Agenturmitteilungen informieren über die gegebenen Ereignisse, sie kommentieren sie allerdings selten. Eine Ausnahme sind Mitteilungen des Typs Dossier oder ein Ereignis analysierende Berichte. Unter den Publikationen beziehen sich die meisten auf Organisationsangelegenheiten oder auf Sachen, die nicht direkt mit dem Inhalt der päpstlichen Lehre zusammenhängen ${ }^{37}$.

Die erste apostolische Reise von Papst Franziskus fand im Jahre 2016 nach Kuba und Mexiko vom 12. bis zum 17. Februar 2016 statt. Am 12. Februar fand das erste in der Geschichte Treffen des Oberhauptes der katholischen Kirche mit dem Vorsteher der russisch-orthodoxen Kirche, dem Patriarchen von Moskau und der ganzen Rus Kyrill am Flughafen in Havanna statt. Das Treffen endete mit Unterzeichnung der katholisch-orthodoxen Gemeinsamen Erklärung, in der die beiden Kirchenvorsteher feststellen, dass die Katholiken und Russisch-Orthodoxen

${ }^{36}$ Siehe [ohne Autor], Papież: Kościół to nie drużyna piłkarska, która zabiega o kibiców, 18.11.2016, in: http://wiadomosci.onet.pl/swiat/papiez-kosciol-to-nie-druzyna-pilkarskaktora-zabiega-o-kibicow/srgrmd, [Zugriff 15.03.2018].

${ }^{37}$ Siehe J. Biedrzycki, Auto-homoterroryzm prawicy, 22.06.2016, in: http://wiadomosci. onet.pl/kraj/auto-homoterroryzm-prawicy/4gsx8h, [Zugriff 15.03.2018]. 
Marcin Wrzos, Apostolische Auslandsreisen von Papst Franziskus, darunter Missionsreisen...

aufgerufen sind, brüderlich in der Verkündigung der Frohen Botschaft über die Erlösung zusammenzuarbeiten und gemeinsam von der Würde und von der authentischen Freiheit des Menschen zu zeugen, damit die Welt glaubt. Sowohl Kyrill als auch Franziskus drückten ihre Freude über die durchgeführten „ehrlichen und offenen" Gespräche aus und betonten, dass beide Kirchen zum Wohl der Christen und der ganzen Welt miteinander zusammenarbeiten können. Somit wurden in den Publikationen ökumenische Aktionen für die Einheit der Christen betont. Unter dem Motto „Missionar der Barmherzigkeit und des Friedens“ hielt sich Franziskus in Mexiko auf - im Lande, wo 90\% der Gesellschaft sich zum Katholizismus bekennt. Die Pilgerreise bestand aus: heilige Messen in der Basilika Unserer Lieben Frau von Guadalupe, in Ecatepec, für Indianer aus dem Bundesstaat Chiapas in San Cristóbal de Las Casas und in Ciudad Juárez, Treffen mit Familien in Tuxtla Gutiérrez, mit der Jugend in Morelia und mit Arbeitern in Ciudad Juárez, Besuch des Federico-Gómez-Kinderkrankenhauses in der Stadt Mexiko und des Gefängnisses in Ciudad Juárez. In sechs Tagen war der Papst in sechs Städten. Heiliger Vater besuchte eines der am meisten katholischen Länder der Welt und gleichzeitig sog. „Peripherien der Welt“, indem er sich mit den in die Randgruppen verdrängten Menschen traf. Im Zusammenhang mit dem Jubiläum der Barmherzigkeit sprach er die sozialen Probleme an, die nicht nur Mexiko sondern auch andere Regionen der Welt betreffen: Armut, die zur Gewalt führt, Drogenhandel und Drogensucht, Korruption, Torturen, organisierte Kriminalität, Menschenhandel und Migration. Insbesondere waren diese letzten Fragen und die Kirchenlehre zu diesen Themen der Gegenstand der Publikationen ${ }^{38}$.

${ }^{38}$ Siehe [ohne Autor], Historyczne spotkanie papieża z patriarcha moskiewskim, 11.02.2016, in: http://fakty.interia.pl/swiat/news-historyczne-spotkanie-papieza-zpatriarcha-moskiewskim,nId,2143675, [Zugriff 15.03.2018]; [ohne Autor], Franciszek i Cyryl: niech Europa będzie wierna chrześcijańskim korzeniom, 12.02.2016, in: http:// wiadomosci.gazeta.pl/wiadomosci/1,114871,19621038,franciszek-i-cyryl-niech-europa-bedzie-wierna-chrzescijanskim.html, [Zugriff 15.03.2018]; [ohne Autor], Historyczne spotkanie papieża Franciszka z patriarchq Cyrylem, 12.02.2016, in: http://fakty.interia.pl/ swiat/news-historyczne-spotkanie-papieza-franciszka-z-patriarcha-cyryle,nId,2145388, [Zugriff 01.03.2016]; [ohne Autor], Papież w Meksyku. Mówił o korupcji, przemocy, handlu narkotykami, 11.02.2016, in: http://wiadomosci.onet.pl/swiat/papiez-w-meksykumowil-o-korupcji-przemocy-handlu-narkotykami/mrmfc0, [Zugriff 15.03.2018].; [ohne Autor], Papież w szpitalu w Meksyku, 18.02.2016, in: http://www.fakt.pl/swiat/papiez-franciszek-w-szpitalu-w-meksyky,artykuly,611128.html, [Zugriff 15.03.2018]; [ohne Autor], Meksyk. Papież prosi Indian o przebaczenie za krzywdy, których doznali, 15.02.2016, in: 
Die eintägige apostolische Reise von Papst Franziskus nach Griechenland fand am 16. April 2016 statt und umfasste die Insel Lesbos. Während des fünfstündigen Besuchs besuchte er zusammen mit dem Patriarchen von Konstantinopel Bartholomäus I. und dem russisch-orthodoxen Erzbischof von Athen und ganz Griechenland Hieronymos II. das sich dort befindende Flüchtlingslager. Sie unterschrieben eine gemeinsame Erklärung über Zusammenarbeit sowie beteten für die, die im Ägäischen Meer bei der Überquerung nach Griechenland ertranken. Bei diesem Besuch riefen die religiösen Vorsteher die Flüchtlinge auf, die Hoffnung nicht zu verlieren. In einer gemeinsamen Erklärung riefen sie die Welt zur Reaktion auf, um sich der humanitären Krise im Zusammenhang mit dieser Menschengruppe und ihren Ursachen zu stellen. Der Papst wies auf die Notwendigkeit einer weit reichenden Politik und nicht von einseitigen und Übergangsaktionen auf. Er gab zu, die mit der Flüchtlingskrise zusammenhängende Furcht der Institutionen, der Menschen in Griechenland und anderen Ländern Europas sei nachvollziehbar und begründet. Er appellierte, dass man trotz dieser Furcht nicht vergaß, dass die Migranten keine „Zahlen, sondern Personen, Gesichte, Namen, Geschichten sind“. Bei der Rückkehr nach Rom nahm er drei syrische Familien mit sich. Neben dieser Geste wurden in den Portalen ökumenische Inhalte und auch die evangelische Hilfe den Ausgeschlossenen umfangreich beschrieben ${ }^{39}$.

http://wiadomosci.gazeta.pl/wiadomosci/1,114877,19630578,meksyk-papiez-prosi-indian-o-przebaczenie-za-krzywdy-ktorych.html, [Zugriff 15.03.2018]; [ohne Autor], Meksyk. Papież: nie popadać w rezygnację w obliczu gangów i przemocy, 16.02.2016, in: http:// wiadomosci.gazeta.pl/wiadomosci/1,114877,19636172,meksyk-papiez-nie-popadac-w-rezygnacje-w-obliczu-gangow-i-przemocy.html, [Zugriff 15.03.2018]; [ohne Autor], Papież zakończył wizytę w Meksyku i wraca do Rzymu, 18.02.2016, in: http://wiadomosci.gazeta. pl/wiadomosci/1,114871,19642683,papiez-zakonczyl-wizyte-w-meksyku-i-wraca-do-rzymu.html, [Zugriff 15.03.2018]; [ohne Autor], Meksyk: Po raz pierwszy papież odprawił mszę na granicy dwóch państw, 18.02.2016, in: http://fakty.interia.pl/swiat/news-meksyk-poraz-pierwszy-papiez-odprawil-msze-na-granicy-dwoch,nId,2147198, [Zugriff 01.03.2016]; [ohne Autor], Papież zakończył wizytę w Meksyku i wraca do Rzymu, 18.02.2016, in: http:// wiadomosci.onet.pl/swiat/papiez-zakonczyl-wizyte-w-meksyku-i-wraca-do-rzymu/8qbv7d, [Zugriff 01.03.2016]; [ohne Autor], Papież wspomina spotkanie z Cyrylem i apeluje o zniesienie kary śmierci, 21.02.2016, in: http://wiadomosci.wp.pl/kat,1356,wid,18174771,martykul. html, [Zugriff 15.03.2018].

${ }^{39}$ Siehe [ohne Autor], Papież, Bartłomiej i Hieronim podpisali deklarację ws. migrantów, 16.04.2016, in: http://wiadomosci.wp.pl/kat,1356,title,Papiez-po-spotkaniu-z-uchodzcamiwidzialem-tyle-bolu,wid,18274373,wiadomosc.html, [Zugriff 15.03.2018]; [ohne Autor], Papież wraca z Lesbos do Rzymu, na pokład samolotu zabrał 12 uchodźców, 16.04.2016, in: 
Marcin Wrzos, Apostolische Auslandsreisen von Papst Franziskus, darunter Missionsreisen...

Die dritte apostolische Reise von Papst Franziskus war in der analysierten Zeit nach Armenien und fand vom 24. bis zum 26. Juni 2016 statt und sie verlief unter dem Motto „Besuch im ersten christlichen Land“. Das gemeinsame Gebet des Papstes und des Katholikos Karekin II. im Dom der Armenischen Apostolischen Kirche in Etschmiadsin, das Treffen mit den Zivilbehörden und dem diplomatischen Korps im Präsidentenpalast, der Besuch im Denkmalkomplex Zizernakaberd in Jerewan, heilige Messe mit tausenden von Gläubigern der armenisch-katholischen Kirche in Giumri, ökumenisches Treffen und Gebet um Frieden am Platz der Republik sowie Teilnahme an der Gottesliturgie der Armenischen Apostolischen Kirche in Jerewan waren Bestandteil des päpstlichen Besuchs in Armenien. Während des Besuchs wurden drei sehr wichtige theologische Themen angesprochen: Gedächtnis, Frieden sowie ökumenischer Dialog und Versöhnung, die ihren Platz in den Portalen fanden. Franziskus erwies seine Ehrerbietung den Vernichtungsopfern und dankte, dass das armenische Volk nach mehr als 100 Jahren nach den durch den Völkermord in Jahren 1915-1917 verursachten Zerstörungen und den sowjetischen Zeiten seine christliche Identität bewahrte. Wieder nannte er Metz Yeghérn - Großes Böse, d. h. das Blutbad von 1,5 Mio. Armeniern „Völkermord“. Sowohl Armenier als auch Publizisten nahmen den päpstlichen Aufruf zur Versöhnung zwischen dem armenischen und türkischen Volk und dass der Frieden auch in Bergkarabach kommt, wo seit mehr als

http://wiadomosci.onet.pl/swiat/papiez-wraca-z-lesbos-do-rzymu-na-poklad-samolotuzabral-12-uchodzcow/h3wwmq, [Zugriff 15.03.2018]; [ohne Autor], Papież: przybyłem na Lesbos, by zwrócić uwagę na kryzys humanitarny, 16.04.2016, in: http://wiadomosci.wp.pl/ kat,1356,wid,18273474,martykul.html, [Zugriff 15.03.2018]; [ohne Autor], Papież po spotkaniu z uchodźcami: widziałem tyle bólu, 17.04.2016, in: http://wiadomosci.wp.pl/kat,1356,title,Papiez-po-spotkaniu-z-uchodzcami-widzialem-tyle-bolu,wid,18274373,wiadomosc.html, [Zugriff 15.03.2018]; T. Cylka, Polscy biskupi w cieniu papieża Franciszka. Czy każda parafia przyjmie jednq rodzinę?, 18.04.2016, in: http://gazeta.pl/1,75398,19934458,polscy-biskupi-w-cieniu-papieza-franciszka-czy-kazda-parafia.html, [Zugriff 15.03.2018]; [ohne Autor], Grecja: starcia w obozie dla migrantów na Lesbos, 26.04.2016, in: http://wiadomosci.onet.pl/ swiat/grecja-starcia-w-obozie-dla-migrantow-na-lesbos/3j3zny, [Zugriff 15.03.2018]; [ohne Autor], Mini szczyt o Europie, 06.05.2016, in: http://fakty.interia.pl/swiat/news-miniszczyt-oeuropie-w-zwiazku-z-nagroda-karola-wielkiego-dl,nId,2197551, [Zugriff 15.03.2018]; T. Bielecki, Papież zabiera uchodźców, 18.04.2016, in: http://wyborcza.pl/1,75399,19934589,papiez-zabiera-uchodzcow.html?disableRedirects=true, [Zugriff 15.03.2018]; [ohne Autor], Niezwykłe gesty papieża Franciszka: normalność jako styl pontyfikatu, 26.05.2016, in: http:// wiad omosci.onet.pl/swiat/niezwykle-gesty-papieza-franciszka-normalnosc-jako-stylpontyfikatu/09yzx6, [Zugriff 15.03.2018]. 
30 Jahren der Konflikt von Armenien mit Aserbaidschan dauert, an. Während des Besuchs zeigten Franziskus sowie der Vorsteher der Armenischen Apostolischen Kirche Karekin II., dass die Beziehungen zwischen den Kirchen Modellbeziehungen sind, wofür ein Beweis war u. a. die Tatsache, dass der Papst im Apostolischen Palast, dem Sitz des Katholikos in Etschmiadsin beherbergte, und während der Gottesliturgie der Name des Papstes zweimal erwähnt wurde, was ein beispielloses Ereignis war, wie es Kommentatoren in den Portalen betonten ${ }^{40}$.

Die apostolische Reise von Papst Franziskus nach Polen fand vom 27. bis zum 31. Juli 2016 statt. Der Besuch von Papst Franziskus in Polen dauerte fünf Tage. Sein Aufenthalt war hauptsächlich mit dem Weltjugendtag in Krakau verbunden, der unter dem Motto „Gesegnet die Barmherzigen, denn sie die Barmherzigkeit erlangen" verliefen und die in den Diözesen und Orden seit dem 20. Juli dauerten. Ferner gedachte Franziskus auf dem Jasna Góra 1050. Jahrestag der Taufe Polens, betete in ergreifenden Stille auf dem Gelände des ehemaligen deutschen Konzentrationslagers Auschwitz-Birkenau und besuchte kranke Kinder in einem Krakauer Krankenhaus. Während der hl. Messe zum Abschluss des WJT ermutigte er die Jugend aus allen Kontinenten, das Evangelium sei ihr "Navigator" auf ihren Lebenswegen. Franziskus sprach zu den Jugendlichen nicht nur während hl. Messe und des Kreuzweges, sondern auch aus dem sog. päpstlichen Fenster in ul. Franciszkańska und er richtete an die Zuhörer konkrete Ratschläge und Hinweise übers Leben, die Ehe, die Krankheit, das Vergehen und das Leiden. Der Weltjugendtag wurde von Katechesen begleitet, die in 33 Sprachen von Bischöfen aus verschiedenen Regionen der Welt geführt waren. Tanzvorstellungen, Spektakel, Sportspiele,

${ }^{40}$ Siehe [ohne Autor], Franciszek o rzeziach Ormian dokonanych przez imperium osmańskie: to ludobójstwo, 24.06.2016, in: http://wiadomosci.wp.pl/kat,1356,wid,18395819,martykul.html, [Zugriff 15.03.2018]; [ohne Autor], Papież nazwał rzeź Ormian ludobójstwem, 25.06.2016, in: http://wiadomosci.onet.pl/swiat/papiez-nazwal-rzez-ormian-ludobojstwem/99s695, [Zugriff 15.03.2018]; [ohne Autor], Papież o sytuacji w Europie. Wojna już tu jest", 27.06.2016, in: http://www.fakt.pl/wydarzenia/polityka/papiez-o-sytuacji-w-europie-ostro/htrz804, [Zugriff 15.03.2018]; [ohne Autor], Papież nazwał rzeź Ormian ludobójstwem, 27.06.2016, in: http://wiadomosci.onet.pl/swiat/papiez-nazwal-rzez-ormian-ludobojstwem/99s695, [Zugriff 15.03.2018]; [ohne Autor], Watykan odrzuca turecką krytykę słów papieża o ludobójstwie Ormian, 27.06.2016, in: http://wiadomosci.wp.pl/kat,1356,title,Watykan-odrzuca-turecka-krytyke-slow-papieza-o-ludobojstwie-Ormian,wid,18397036,wiado mosc.html, [Zugriff 15.03.2018]; M. Makowski, Polka za murami Watykanu. Niezwykłe życie u boku dwóch papieży, 28.06.2016, in: http://kobieta.onet.pl/dziecko/wychowanie/polka-zamurami-watykanu-niezwykle-zycie-u-boku-dwoch-papiezy/kh85pj, [Zugriff 15.03.2018]. 
Marcin Wrzos, Apostolische Auslandsreisen von Papst Franziskus, darunter Missionsreisen...

Filmvorführungen, Konferenzen und Evangelisierungstreffen in den Kirchen waren Bestandteil des Festivals der Jugend. In einigen Dutzenden Orten in Krakau und der Gegend fanden rund 250 Bildungs-, Kultur- und Sportereignisse statt, vorbereitet von vielen bekannten christlichen Künstlern aus der ganzen Welt ${ }^{41}$.

${ }^{41}$ Beispielhafte Nachrichten aus den 1420 analysierten zum Thema der päpstlichen Pilgerreise nach Polen: Siehe [ohne Autor], Papież tuż przed wyjściem do okna na Franciszkańskiej 3, 27.07.2016, in: http://wiadomosci.wp.pl/kat,1342,wid,18442731,martykul.html, [Zugriff 15.03.2018]; [ohne Autor], ŚDM w Krakowie. Papież Franciszek: naród polski może liczyć na współprace Kościoła, 27.07.2016, in: http://wiadomosci.wp.pl/ kat,1342,title,SDM-w-Krakowie-Papiez-Franciszek-narod-polski-moze-liczyc-na-wspolpraceKosciola,wid,18442159,wiadomosc.html, [Zugriff 15.03.2018]; [ohne Autor], Siostra Chmielewska $z$ synem $w$ tramwaju $z$ papieżem, 28.07.2016, in: http://www.fakt.pl/wydarzenia/ polska/sdm-krakow-siostra-chmielewska-z-synem-w-tramwaju-z-papiezem/wmdc416, [Zugriff 15.03.2018]; [ohne Autor], Wystąienie papieża Franciszka wygłoszone na krakowskich Błoniach 28 lipca, 28.07.2016, in: http://fakty.interia.pl/raporty/raport-swiatowe-dni-mlodziezy-krakow-2016/czwartek/news-wystapienie-papieza-franciszkawygloszone-na-krakowskich-blo,nId,2243370, [Zugriff 15.03.2018]; [ohne Autor], Biskupi skomentowali homilię papieża. "Pierwszym uczuciem jest radość", 28.07.2016, in: http://fakty.interia.pl/raporty/raport-swiatowe-dni-mlodziezy-krakow-2016/czwartek/newsbiskupi-skomentowali-homilie-papieza-pierwszym-uczuciem-jest,nId,2243276, [Zugriff 15.03.2018]; [ohne Autor], Pomyłka w tłumaczeniu słów Franciszka. "Hałasujcie cała noc!", 28.07.2016, in: http://wiadomosci.onet.pl/kraj/sdm-2016-slowa-papieza-franciszkablednie-przetlumaczone/2qjjfj, [Zugriff 15.03.2018]; [ohne Autor], Papież Franciszek odprawił mszę na Jasnej Górze. Kilkaset tysięcy wiernych., 28.07.2016, in: http://wiadomosci.wp.pl/gid,18442994,kat,7631,mgaleria.html, [Zugriff 15.03.2018]; [ohne Autor], ŚDM 2016 w Krakowie. Papież Franciszek przemówił do zgromadzonych, 29.07.2016, in: http:// www.fakt.pl/wydarzenia/polska/krakow/sdm-2016-w-krakowie-tlumy-pod-oknempapieza-franciszka-relacja-na-zywo/qx05ndp, [Zugriff 15.03.2018]; [ohne Autor], Papież: Okrucieństwo nie skończyło się w Auschwitz-Birkenau, istnieje także i dziś, 29.07.2016, in: http://fakty.interia.pl/raporty/raport-swiatowe-dni-mlodziezy-krakow-2016/aktualnosci/news-papiez-okrucienstwo-nie-skonczylo-sie-w-auschwitz-birkenau-i,nId,2244071, [Zugriff 15.03.2018]; [ohne Autor], Na krakowskich Błoniach odbyła się Droga Krzyżowa, 29.07.2016, in: http://wiadomosci.onet.pl/krakow/sdm-2016-w-krakowie-na-bloniachodbywa-sie-droga-krzyzowa/eb4gtx, [Zugriff 15.03.2018]; M. Suchan, "Przebiegły plan papieża Franciszka". Co papież chce przekazać młodym?, 30.07.2016, in: http://wiadomosci.onet.pl/kraj/przebiegly-plan-papieza-franciszka-co-papiez-chce-przekazac-mlodym/ jnh04y, [Zugriff 15.03.2018]; [ohne Autor], Papież odprawił mszę św. w Sankturaium św. Jana Pawła II, 30.07.2016, in: http://wiadomosci.onet.pl/krakow/sdm-2016-papiez-franciszekmsza-w-sanktuarium-sw-jana-pawla-ii/lpy28v, [Zugriff 15.03.2018]; [ohne Autor], Papież na Campus Misericordiae, 30.07.2016, in: http://wiadomosci.wp.pl/kat,1329,title,Papiezna-Campus-Misericordiae,wid,18447229, martykul.html, [Zugriff 15.03.2018]; [ohne Autor], Franciszek dziękuje: Napełniliście Kraków entuzjazmem waszej wiary, 31.07.2016, in: http://fakty.interia.pl/raporty/raport-swiatowe-dni-mlodziezy-krakow-2016/niedziela/ 
Die apostolische Reise von Papst Franziskus nach Georgien und Aserbaidschan fand vom 30. September bis zum 2. Oktober 2016 statt. Sie war die fünfte im analysierten Jahr. Treffen mit dem russisch-orthodoxen Katholikos - dem Patriarchen von ganz Georgien Ilia II., hl. Messe auf dem Micheil-Meschi-Stadion in

news-franciszek-dziekuje-napelniliscie-krakow-entuzjazmem-waszej-,nId,2244432, [Zugriff 15.03.2018]; [ohne Autor], Gorq̨e komentarze po decyzji papieża Franciszka, 31.07.2016, in: http://www.fakt.pl/www.fakt.pl/wydarzenia/polska/swiatowe-dni-mlodziezy-nastepnesdm-w-panamie-w-2019-roku/n6rh3tl, [Zugriff 15.03.2018]; [ohne Autor], Papież Franciszek żegnany $w$ strugach deszczu, 01.08.2016, in: http://wiadomosci.onet.pl/krakow/sdm-2016papiez-franciszek-w-balicach-zegnany-byl-w-strugach-deszczu/6jw0mr, [Zugriff 15.03.2018]; [ohne Autor], Prymas: papież pokazał chrześcijańskie miłosierdzie wobec uchodźcy, 01.08.2016, in: http://fakty.interia.pl/raporty/raport-swiatowe-dni-mlodziezy-krakow-2016/komentarze/news-prymas-papiez-pokazal-chrzescijanskie-milosierdzie-wobec-uch,nId,2244857, [Zugriff 15.03.2018]; [ohne Autor], Przesłanie papieża Franciszka po Światowych Dniach Młodzieży, 01.08.2016, in: http://wiadomosci.wp.pl/gid,18448829,kat,,title,Przeslanie-pap ieza-Franciszka-po-Swiatowych-Dniach-Mlodziezy,galeria.html, [Zugriff 15.03.2018]; [ohne Autor], Papież Franciszek wybrał najlepszego piłkarza, 01.08.2016, in: http://ofsajd.onet.pl/ plotki/papiez-franciszek-wybral-najlepszego-pilkarza/hec1x8, [Zugriff 15.03.2018]; [ohne Autor], ŚDM: 300 tys. pielgrzymów wyjechało w niedzielę pociągami z Krakowa, 01.08.2016, in: http://biznes.onet.pl/wiadomosci/kraj/sdm-300-tys-pielgrzymow-wyjechalo-w-niedzielepociagami-z-krakowa/zgtdnn, [Zugriff 15.03.2018]; [ohne Autor], Co warto wiedzieć o Panamie - następnym gospodarzu ŚDM?, 03.08.2016, in: http://wiadomosci.onet.pl/kraj/co-wartowiedziec-o-panamie-nastepnym-gospodarzu-sdm/r7s56j, [Zugriff 15.03.2018]; [ohne Autor], Młodzieżowy język papieża, 03.08.2016, in: http://wiadomosci.wp.pl/gid,18449239,gpage,6,img,18449422,kat,1342,title,Zagraniczne-komentarze-po-wizycie-papieza-Franciszka-w-Polsce,galeria.html, [Zugriff 15.03.2018]; [ohne Autor], Witold Waszczykowski dla WP: gdyby Franciszek poruszył sprawę Smoleńska, to były olbrzymi sukces, 03.08.2016, in: http:// wiadomosci.wp.pl/kat,1342,wid,18448911,martykul.html, [Zugriff 15.03.2018]; [ohne Autor], Abp Gądecki dziękuje prezydentowi Andrzejowi Dudzie za udział w ŚDM, 04.08.2016, in: http://wiadomosci.onet.pl/kraj/abp-gadecki-dziekuje-prezydentowi-andrzejowi-dudzieza-udzial-w-sdm/9nq4bq, [Zugriff 15.03.2018]; [ohne Autor], Listy gratulacyjne dla polskich służb, 06.08.2016, in: http://fakty.interia.pl/raporty/raport-swiatowe-dni-mlodziezy-krakow-2016/aktualnosci/news-listy-gratulacyjne-dla-polskich-sluzb-zabezpieczajacych-sdm,nId,2247668, [Zugriff 15.03.2018]; [ohne Autor], Papież w Auschwitz. Stary człowiek daje mu to zdjęcie. "Chłopiec w trzecim rzędzie prycz to ja", 15.09.2016, in: http://weekend.gazeta.pl/ weekend/1,152121,20683847,papiez-w-auschwitz-stary-czlowiek-daje-mu-to-zdjecie-chlopiec.html, Zugriff 15.03.2018]; A. Szczepańska, Narodowa pielgrzymka Polaków, 21.10.2016, in: http://fakty.interia.pl/religia/news-narodowa-pielgrzymka-polakow,nId,2294693, [Zugriff 15.03.2018]; [ohne Autor], Rozpoczyna się cykl spotkań dla młodych po ŚDM, 24.10.2016, in: http://krakow.onet.pl/rozpoczyna-sie-cykl-spotkan-dla-mlodych-po-sdm/k7g65c, [Zugriff 15.03.2018]; [ohne Autor], Rozpoczyna się cykl spotkań dla młodych po ŚDM, 24.10.2016, in: http://krakow.onet.pl/rozpoczyna-sie-cykl-spotkan-dla-mlodych-po-sdm/k7g65c, [Zugriff 15.03.2018]. 
Marcin Wrzos, Apostolische Auslandsreisen von Papst Franziskus, darunter Missionsreisen...

Tiflis, Treffen mit Priestern, Ordensschwestern und Ordensbrüdern in der Kirche der in den Himmel aufgefahrenen Gottesmutter und den Betreuten der kirchlichen karitativen Werke, darunter im karitativen Zentrum der Kamillianer in Tiflis sowie der Besuch in der Swetizchoweli-Kathedrale in Mzcheta waren die Hauptereignisse des apostolischen Besuchs von Franziskus in Georgien. Er verlief unter dem Motto „Frieden euch“. Die sechszehnte Auslandsreise des Papstes war die zweite Etappe seiner Reise nach Kaukasusländer. Im Juni war er in Armenien. Aus Tiflis begab er sich nach Aserbaidschan. Gemäß dem Motto der Pilgerreise kam der Papst nach Georgien mit einer Friedensmission. Im Zusammenhang mit dem Konflikt wegen der seit 2008 durch Russland besetzten Gebiete von Abchasien und Südossetien betete er und appellierte um friedliche Lösung der Konflikte sowie warnte, damit ethnische, sprachliche, religiöse und politische Unterschiede nicht als „Vorwand auszunutzen, Konflikte in endlose Tragödien umzuwandeln“. Ökumenismus und auch Theologie der Versöhnung und der Barmherzigkeit wurden in den diese Pilgerreise betreffenden und in den Portalen veröffentlichten Nachrichten betont. Franziskus, Fürsprecher des ökumenischen Friedens und der Versöhnung, erinnerte daran, dass trotz der Einschränkungen und unabhängig von sämtlichen späteren historischen und Kulturunterschieden sind die katholische Kirche und der russisch-orthodoxe Kirche Georgiens zur Einheit im Namen des Evangeliums aufgerufen.

Hl. Messe in der Unbefleckte-Maria-Kirche, Gespräche mit Behörden im Heydar-Aliyev-Zentrum sowie religionsübergreifende Gespräche mit Beteiligung des Scheichs von Kaukasus und der Vertreter anderer Religionsgemeinschaften des Landes waren die Hauptereignisse des zehnstündigen Besuchs von Franziskus am 2. Oktober in Aserbaidschan. Er verlief unter dem Motto: „Wir alle sind Brüder“. Nach Georgien war dieses Land die letzte Etappe des Papstes. Ähnlich wie in Armenien kam Franziskus nach Aserbaidschan mit der Friedensmission. Im Zusammenhang des seit 1993 dauernden Konflikts zwischen Aserbaidschan und Armenien wegen Bergkarabach ermutigte er alle, „Himmel und Erde in Bewegung zu setzen, um eine zufriedenstellende Lösung der existierenden Spannungen im Kaukasus zu erreichen“. Der zweite wichtige Aspekt des päpstlichen Besuchs war religionsübergreifender Dialog. Franziskus erinnerte daran, dass Gott für eigene partikulären Interessen und egoistische Ziele nicht gerufen werden darf und dass Er kein Fundamentalismus, Imperialismus oder Kolonialismus rechtfertigen 
kann. In den veröffentlichten Texten tritt die Frage des Friedens und des religionsübergreifenden Dialogs auf ${ }^{42}$.

Weitere Auslandsreise von Franziskus vom 31. Oktober bis zum 1. November hatte ökumenischen Charakter und sie fand anlässlich der beginnenden Gedenkfeier zum 500. Jahrestag der Reformation und auch um des 50. Jahrestages des erfolgreichen katholisch-lutherischen Dialogs zu gedenken statt. Der Papst traf sich mit der einheimischen, aus mehreren Nationalitäten bestehenden katholischen Gemeinschaft, für die er hl. Messe in Malmö am Allerheiligentag lies. Während des Gottesdienstes in der lutherischen Kathedrale in Lund erinnerte der Papst an den Beitrag der aus der Reformation entstandenen Kirchen zur Anerkennung der Zentralstelle der Heiligen Schrift im Leben der Kirche. Er wies auf die Bedeutung der geistlichen Erfahrung von Martin Luther sowie der Lehre über Rechtfertigung hin, die der Kern des menschlichen Lebens vor Gott ausdrückt. Es wurde eine gemeinsame katholisch-lutherische Erklärung unterzeichnet. In der Sporthalle Malmö Arena fand unter dem Motto „Zusammen in der Hoffnung“ ein Gespräch statt, das der zweite Teil der gemeinsamen Gedenkfeier zur Eröffnung des Reformationsjubiläums bildete. In der Rede dankte der Papst den Regierungen, die den Flüchtlingen und Asylbewerbern helfen. Anschließend wurde die Intentionserklärung zwischen Caritas Internationalis und der Abteilung für die Dienst für die Welt des Lutherischen Weltverbunds unter dem Titel „Zusammen in der Hoffnung“. Am 1. November traf sich Franziskus mit den Katholiken und lies für sie heilige Messe auf dem Stadion Swedbank in Malmö. In der Homilie sprach

${ }^{42}$ Sieh [ohne Autor], Papież Franciszek już w Gruzji, 30.09.2016, in: http://wiadomosci.wp.pl/kat,1356,wid,18525229,martykul.html, [Zugriff 15.03.2018]; [ohne Autor], Papież Franciszek w Gruzji: trwa wojna światowa, by zniszczyć małżeństwo, 01.10.2016, in: http:// wiadomosci.wp.pl/kat,1356,wid,18526755,martykul.html, [Zugriff 15.03.2018]; [ohne Autor], Papież w Azerbejdżanie o słowach Jana Pawła II, 02.10.2016, in: http://fakty.interia. $\mathrm{pl} /$ swiat/news-papiez-w-azerbejdzanie-o-slowach-jana-pawla-ii,nId,2284202, [Zugriff 15.03.2018]; [ohne Autor], Franciszek w Azerbejdżanie, 02.10.2016, in: http://fakty.interia.pl/galerie/swiat/zdjecie,ild,2158902,iAId,215387, [Zugriff 15.03.2018]; [ohne Autor], Franciszek komentuje nie wypełnienie testamentu Jana Pawła II, 03.10.2016, in: http://wiadomosci.wp.pl/kat,9972,wid,18527783,martykul.html, [Zugriff 15.03.2018]; S. Wysocka, Gruzja ma problem z Rosja, 05.10.2016, in: http://fakty.interia.pl/religia/news-franciszek-ohomoseksualistach-towarzyszylem-im-i-nigdy-nie-,nId,2284267, [Zugriff 15.03.2018]; [ohne Autor], Papież: starałem się wesprzeć narody Gruzji i Azerbejdżanu, 05.10.2016, in: http://wiadomosci.onet.pl/swiat/papiez-staralem-sie-wesprzec-narody-gruzji-i-azerbejdzanu/pkc6wt, [Zugriff 15.03.2018]. 
Marcin Wrzos, Apostolische Auslandsreisen von Papst Franziskus, darunter Missionsreisen...

Franziskus über die allgemeine Berufung zur Heiligkeit und wies auf die Aktualität der evangelischen Segen sowie dringende Notwendigkeit, nach der Einheit der Christen zu streben, hin. Einheit der Christen, ökumenische Bewegung, Theologie der Barmherzigkeit sind theologische Inhalte, die in den mit dieser Pilgerreise verbundenen Portalpublikationen bemerkbar sind ${ }^{43}$.

Rund 70\% der Publikationen in den analysierten Internetportalen über die päpstlichen Auslandsreisen im Jahre 2016 sind Mitteilungen von Nachrichtenagenturen. Es kommt vor, dass die Mitteilungen in verschiedenen Internetdiensten kopiert werden. Die päpstlichen Pilgerreisen hatten insbesondere im Jahre 2016 ökumenischen Charakter, sie waren mit dem religionsübergreifenden Dialog, den Flüchtlingen oder der Evangelisierung verbunden. Die in den Laienmedien veröffentlichten theologischen Inhalte waren somit mit Ekklesiologie, Theologie der Barmherzigkeit, Dialog, Ökumenismus und religionsübergreifendem Dialog verbunden. Man konzentrierte sich darin auf der Darstellung der überzeugenden Kirche, die nach Papst Franziskus eine solche wird, wenn sie beginnt, mit Sorge um den Menschen, insbesondere um den ausgeschlossenen und ausgeschiedenen zu leben.

\section{PASTORALE SCHLUSSFOLGERUNGEN}

Die erste Papstbotschaft zum Welttag der Massenmedien wurde nach dem 2. Vatikanischen Konzil im Jahre 1967 vom Papst Paulus VI. veröffentlicht. Die mit neuen Medien, darunter mit den Portalen zusammenhängenden Inhalte wurden darin allerdings erst ab 1990 aufgenommen. Es war sowieso eine schnelle Reaktion

${ }^{43}$ Siehe [ohne Autor], Niemcy świętuja 500-lecie Reformacji, 31.10.2016, in: http:// fakty.interia.pl/religia/news-niemcy-swietuja-500-lecie-reformacji,nId,2299221, [Zugriff 15.03.2018]; [ohne Autor], Papież w protestanckiej Szwecji mówił o reformacji, 01.11.2016, in: http://fakty.interia.pl/swiat/news-papiez-w-protestanckiej-szwecji-mowilo-reformacji,nId,2299342, [Zugriff 15.03.2018; [Bez autora], Papież Franciszek $w$ podróży do Szwecji, 31.10.2016, in: http://wiadomosci.onet.pl/swiat/papiez-franciszek-w-podrozy-do-szwecji/6d3g07, [Zugriff 15.03.2018]; [ohne Autor], Papież odprawił mszę dla 15 tysięcy wiernych na stadionie w Malmoe, 01.11.2016, in: http://wiadomosci.wp.pl/kat,1356,wid,18567625,martykul.html, [Zugriff 15.03.2018]; [ohne Autor], Papież: Kościół to nie drużyna piłkarska, która zabiega o kibiców, 18.11.2016, in: http://wiadomosci.onet.pl/swiat/papiezkosciol-to-nie-druzyna-pilkarska-ktora-zabiega-o-kibicow/srgrmd, [Zugriff 15.03.2018]. Umfangreicher sind die Pilgerreisen von Papst Franziskus in KAI beschrieben. 
aufs Erscheinen des Internets, das ein Hauptträger neuer Medien ist. Johannes Paul II sprach sie immer öfter in seinen Botschaften direkt an, was zu einer Regel ab 2009, d. h. ab den Pontifikaten von Benedikt XVI. und dann von Franziskus wurde. Mit der Zeit begannen zusammen mit der Entwicklung der Digital- und Medientechnik folgende Begriffe in den analysierten Botschaften zu erscheinen: „neue Medien“, „Globalisierung“, „Mobiltelefone“, „Cyberspace“, „SMS“. Die Päpste wiesen immer auf die Rolle dieser Medien in der Gestaltung der heutigen Zivilisation hin, sowohl auf die Chance, die dieser Raum gibt, als auch auf die Gefahren. Sie wiesen auf die Notwendigkeit der christlichen Formation sowohl der Sender als auch der Empfänger. Sie glaubten, sie sind zur Evangelisierung und einer gewissenhaften ekklesischen Information zu nutzen. Neue Medien sollen ein gegenwärtiger Areopag werden, ein Ort des Treffens, in der Dialogkultur, auch für Menschen unterschiedlicher Religionen und Kulturen. Sie sind eine Chance für die Vertiefung der Bindungen, jedoch auch eine Gefahr.

Die Anwesenheit der Gemeinschaft der Kirche und ihrer Institution im virtuellen Raum, insbesondere im Laienraum, ist notwendig und sogar unerlässlich, um die Evangelisierung mithilfe aller verfügbaren Mittel zu führen. Internet kann als vielschichtiger Raum sowohl ein Ort des Gedankenaustauschs, der Evangelisierung, als auch ein Werkzeug der Verkündung von Evangelium werden. J. Kloch erhebt eine Forderung, das Internet auch als Werkzeug der Evangelisierung zu nutzen. Er glaubt, die Kirche, ihre partikulären Gemeinschaften und Institutionen sollen dieses Werkzeug zur Verkündung der Frohen Botschaft (Evangelisierung, Katechesen, Information), zum Heiligen (Bibel, Gebet, Exerzitien, Informationen über Pilgerreisen), zum Verbreiten der Wohltätigkeit (Sozialhilfe, Freiwilligendienst, Zusammenarbeit, Bilden der Gemeinschaft um die Initiative) und zum Lehren (theologische Reflexion, Bildung der ekklesischen Gemeinschaft) ${ }^{44}$.

Obwohl die Reichweite der christlichen Internetportale nicht groß ist, wird die Kirchenlehre darin dargestellt. In den Laienportalen sind jedoch die Kirche und die Kirchenlehre schwach anwesend. Die Frage der Erlangung der Daten ist erwähnenswert. Die meisten Nachrichten in den analysierten Portalen (www. onet.pl; www.wp.pl; www.interia.pl; www.gazeta.pl; www.o2.pl; www.fakt.pl) wurden während der jeweiligen päpstlichen Pilgerreise und die übrigen bis 10 Tage davor und 10 Tage danach, obwohl in einigen Fällen es nur drei Tage waren,

${ }^{44}$ Siehe J. Kloch, Kościół w Polsce wobec Web 2.0, Kielce 2013, S. 209-278. 
Marcin Wrzos, Apostolische Auslandsreisen von Papst Franziskus, darunter Missionsreisen...

veröffentlicht. Die die jeweilige Pilgerreise betreffenden Informationen „lebten“ somit ein paar Tage in den am meisten meinungsbildenden Portalen und zudem gab es wenig davon, denn im Durchschnitt weniger als 35 je apostolischer Besuch (32), ohne die Pilgerreise von Papst Franziskus nach Polen zu rechnen. Darunter gab es auch solche, z. B. betreffen Schweden oder Aserbaidschan, wo die Benachrichtigung über die päpstliche Pilgerreise sehr gering war bzw. mit der Beendigung der Pilgerreise zusammenfiel. Es wurde noch kein Werkzeug bearbeitet, das prüfen lässt, wie lange die jeweilige Nachricht auf der Hauptseite bleibt. Möglicherweise waren es nur Stunden oder Minuten. Am meisten wurden kopierte Agenturnachrichten ohne Kommentar veröffentlicht. Eine Ausnahme waren hier die Portale, die mit den katholischen Redaktionen eng zusammenarbeiten. Die engste Zusammenarbeit nahm der Portal www.onet.pl mit „Tygodnik Powszechny“ auf. Das Portal www.interia.pl nutze manchmal die Texte von „Przewodnik Katolicki“. In diesen Portalen kann man die meisten theologische Besprechungen und breitere Übermittlung der päpstlichen Lehre sehen. Es scheint, es sei der richtige Weg, damit so viele wie möglich mit dem Leben der Kirche verbundenen Informationen in den Internetmedien veröffentlicht werden und damit sie zuverlässig dargestellt werden. Um zur Veröffentlichung solcher Inhalte in diesen Portalen zu führen, müssen sie den Redaktionen zur Verfügung gestellt werden. Die Redaktionen sollen auch eine enge Zusammenarbeit mit bestimmtem katholischen Medium bzw. einem Theologen - Journalisten gewährleistet haben.

Es lohnt sich, dass die zentralen Kircheninstitutionen wie Nachrichtenbüro der Polnischen Bischofskonferenz oder der Pressesprecher der Apostolischen Nuntiatur eine Gruppe Menschen bilden würden, die sich mehr um die Anwesenheit der Kirche in den Medien durch Erstellung von die päpstlichen Pilgerreisen vorbereitenden bzw. zusammenfassenden Texten kümmern möchten. Wichtig, dass die Texte kommunikativ für den Empfänger sind und dass sie gemäß den Regeln des Internetjournalismus vorbereitet werden. Es können Laienfreiwilligen tun, den es lohnt sich, zu vertrauen und diesen Teil der Funktion der Kirch als den zu überlassen, die besser damit umgehen können. Die Redaktionen, die fertige Mitteilungen, Besprechungen erhalten, werden ein Werkzeug haben sie zu nutzen. Ein Teil davon nutzt keine Informationen von KAI aufgrund der Gebührenpflicht.

Gemäß der Forderung von J. Kloch ist eine breitere Anwesenheit der Kirche in den Internet- und Laienmedien möglich. Durch die Zusammenarbeit mit Internetmedien, die sich dafür interessieren, ist ihre noch breitere Nutzung möglich, 
insbesondere zur Evangelisierung, zu Katechesen, zur Information, zur Verkündung der ekklesischen Lehre zum jeweiligen Thema oder zum Bilden einer Gemeinschaft der Menschen, die sich an einer Initiative beteiligen möchten. Eine Voraussetzung scheint die Zusammenarbeit der Kirche mit diesen Medien und das Wirken der Menschen, die neue Medien nutzen können, zu sein. Die Pilgerreisen des Papstes, seine Lehre, Missionen, Engagement für ausgeschiedene Personen, Tätigkeit der Jugend sind Themen, die ein positives Image der Kirche in neuen Medien bilden sollten.

Die Welt und die menschlichen Gewohnheiten ändern sich schnell. Zuerst erschienen unter den sozialen Kommunikationsmitteln Zeitschriften, Radio, Fernsehen und heute ist das Internet sowie neue Medien das am meisten verbreitete Medium, das rund 70\% der polnischen Gesellschaft nutzt. Junge Leute lesen sporadisch Zeitschriften, hören Radio, am häufigsten sind sie stets „online“ anhand der Computer und der Mobilgeräte (Telefone, Tablets, Uhren, Handschuhe usw.). Neben den Internetmedien wie Internetseiten, sozialen Medien (Facebook, Twitter, Google+, Instagram oder Pinterest) spielen derzeit die größte Rolle die beliebtesten publizistischen Portale. Manche von ihnen erreichen mehr als 18,2 Mio. Leser monatlich, die das Portal auch ein paar Mal täglich lesen (www.onet.pl). In ihren Ressourcen sollen sich mit der Kirche, darunter auch mit den päpstlichen Pilgerreisen zusammenhängende Informationen befinden.

Aus den durchgeführten Forschungen geht es hervor, dass die päpstlichen Pilgerreisen kleines bzw. mittel kleines Interesse der Portale genossen. Aus den sechs päpstlichen Pilgerreisen (12.-17. Februar 2016 - Kuba, Mexiko; 16. April 2016 - Griechenland; 24.-.26 Juni 2016 - Armenien; 27.-31. Juli 2016 - Polen; 30. September - 2. Oktober 2016 - Georgien, Aserbaidschan; 31. Oktober - 1. November 2016 - Schweden) wurden 1580 Nachrichten veröffentlicht. Nach Abzug der mit der Pilgerreise nach Polen sind es lediglich 160, somit 32 Nachrichten im Durchschnitt je Pilgerreise. Die meisten Nachrichten waren nach der Katholischen Informationsagentur (KAI), der Polnischen Nachrichtenagentur (PAP), der Rundfunkinformationsagentur (RAI) und Radio Vatikan (RV) veröffentlicht. Ihre Anzahl beträgt 1099 von 1580, was 69,6\% der gesamten, oft kopierten Informationen in verschiedenen Portalen darstellt. Die Zeit der Veröffentlichung entsprach meistens der Zeit der apostolischen Reise selbst. Manchmal wurde sie durch Ankündigungen bzw. Zusammenfassungen eingeleitet, am häufigsten wurden sie 
jedoch nicht früher als 7 Tage veröffentlicht. Die sogenannte Lebensdauer einer päpstlichen Pilgerreise im Portal betrug durchschnittlich 7 Tage (so lange erschienen die Nachrichten zu diesem Thema, obwohl sie auf der Hauptseite nur für 2-3 Stunden anwesend waren) unter der Voraussetzung, dass die Pilgerreise überhaupt von der Redaktion des jeweiligen Portals bemerkt wurde. Der Anteil an negativen, positiven und neutralen Nachrichten war unter den Portalen www. onet.pl, www.interia.pl, www.wp.pl und www.gazeta.pl vergleichbar. Hingegen waren die Verhältnisse der negativen Nachrichten gegenüber den positiven und neutralen weniger panegyrisch in den Portalen www.fakt.pl i www.o2.pl.

Es scheint, dass die Zusammenarbeit mit den Internetmedien enger sein sollte. Die zentralen Institutionen der Kirche hätten bei der Vorbereitung der Informationen über die Tätigkeit der Kirche, bei der Zusammenarbeit mit den Laienredaktionen die Chance, ein positives Image zu kreieren sowie mehr Informationen oder theologischen Kommentaren zu veröffentlichen. Es ist wichtig, dass die Theologen, darunter Geistlichen, vorbereitet sind, sich der zu einem solchen Journalismus notwendigen Werkzeuge zu bedienen. Die Pilgerreisen des Papstes, seine Lehre, Missionen, Engagement für ausgeschiedene Personen, Tätigkeit der Jugend sind Themen, die ein positives Image der Kirche in neuen Medien bilden sollten.

Als Zusammenfassung und Antwort auf die Forschungshypothesen scheint es, dass die erste: „Die Medien in Polen informieren sachgemäß über die Auslandspilgerreisen von Papst Franziskus (quantitativ und qualitativ)“ unbestätigt ist. Die zweite: „Die Vorbereitung der Geistlichen zur Benutzung neuer Medien und zur Benachrichtigung über die mit der Kirche verbundenen Fragen ist sachgemäß“ ist unbestätigt; und die dritte: „Die Anzahl der Informationen und die Benachrichtigungsart über die Auslandspilgerreisen ist ungenügend“ bestätigt ist.

\section{Bibliografie}

\section{A. Analysierte Dienste.}

https://www.fakt.pl, [Jahr 2016].

https://www.gazeta.pl, [Jahr 2016].

https://www.interia.pl, [Jahr 2016].

https://www.o2.pl, [Jahr 2016].

https://www.onet.pl, [Jahr 2016].

https://www.wp.pl, [Jahr 2016]. 


\section{B. Sonstige Publikationen:}

Benedikt XVI., Orędzie na 43. Światowy Dzień Środków Społecznego Przekazu. Nowe technologie, nowe relacje. Trzeba rozpowszechniać kulturę szacunku, dialogu i przyjaźni, 24. Januar 2009.

Chudziński E. (Red.), Słownik wiedzy o mediach, Warszawa - Bielsko-Biała 2007.

Franziskus I., Orędzie na 50. Światowy Dzień Środków Społecznego Przekazu Komunikacja i Miłosierdzie - owocne spotkanie, 24. Januar 2016.

Franziskus I., Orędzie na 52. Światowy Dzień Środków Społecznego Przekazu «Prawda was wyzwoli» (J 8, 32). Fake news a dziennikarstwo pokoju“, 24. Januar 2018.

Johannes Paul II., Orędzie na 24. Światowy Dzień Środków Społecznego Przekazu, Misja Kościoła $w$ erze komputerów, 24. Januar 1990.

Kloch J., Kościół w Polsce wobec Web 2.0, Kielce 2013.

Wrzos M., Zagraniczne podróże apostolskie, $w$ tym misyjne, papieża Franciszka $w$ najważniejszych krajowych portalach internetowych, cz. I (lata 2013-2014), in: „Kultura-Media-Teologia", 1 (28) 2017, S. 111-141.

Wrzos M., Zagraniczne podróże apostolskie, $w$ tym misyjne, papieża Franciszka $w$ najważniejszych krajowych portalach internetowych, cz. II (rok 2015); in: „Kultura-Media-Teologia", 4 (31) 2017, S. 140-179.

\section{Biogramm}

Marcin Wrzos OMI (geb. 1977), Priester, Missionar Oblate der Makellosen Jungfrau Maria; Doktor der Theologie im Fachgebiet Missionswissenschaft und Theologie der sozialen Kommunikationsmittel UKSW (2013), er absolvierte das Studium in politischen Wissenschaften und Journalismus UAM (2008) sowie Polonistik UJ (2016). Autor von Artikeln über Missionen in den sozialen Kommunikationsmitteln sowie über Nutzung der sozialen Kommunikationsmittel in Missionen. Er forscht die Anwesenheit der Kirche im Internet. Autor von vier Buchpublikationen: „Polskie czasopisma misyjne po II wojnie światowej. Studium misjologiczno-prasoznawcze“ „Bibliografia polskich czasopism misyjnych. Lata 1945-2013“, „Oblates missionary press in Europe“ (Redakteur) und „Główne idee teologiczne, historia i funkcje oblackiego czasopiśmiennictwa misyjnego w Polsce (19262016)“ sowie von mehr als zehn wissenschaftlichen Artikeln. Ei ist freier Mitarbeiter der Fakultäten für Theologie der Universitäten UAM und USz. Er leitet die Veröffentlichung von „Misyjne Drogi“ und das Internetportal misyjne.pl. 